\title{
PERFORMANCE-AS-RESISTANCE AND RESISTANCE-AS- PERFORMANCE IN THE NO MUOS MOVEMENT IN SICILY
}

\author{
Marcello Messina ${ }^{1}$
}

\begin{abstract}
One of the US-owned Mobile User Objective System (MUOS) installations was projected and built in Sicily, near Niscemi. Since 2012, NO MUOS activists have excogitated various forms of protest that are reminiscent of artistic performances and identitarian rituals. Additionally, a number of creators/performers across different art forms have supported the movement by referring to the NO MUOS resistance in their work. This article seeks to explore the connection between protest and performance in the symbolic practices staged within and outside the picket line. I argue that these protests/ performances possess an identitarian content that points to the reclamation of Sicily's sovereignty against the hysteric militarisation of an imaginary North/South border in the Mediterranean.
\end{abstract}

\section{KEYWORDS}

MUOS, Sicily, Sovereignty, Resistance, Performance

\section{PERFORMANCE DE RESISTÊNCIA E RESISTÊNCIA COMO PERFORMANCE NO MOVIMENTO “NO MUOS”, NA SICÍLIA}

\section{RESUMO}

Uma das instalações do Mobile User Objective System (MUOS), de propriedade dos EUA, foi construída e instalada na Sicília, perto do município de Niscemi. Desde 2012, ativistas do movimento NO MUOS (Não Muos) excogitaram várias formas de protesto que lembram performances e rituais identitários. Ao mesmo tempo, vários artistas suportaram o movimento fazendo referência à resistência do NO MUOS nas suas obras. Este artigo pretende estudar a conexão entre resistência e performance em práticas simbólicas encenadas dentro e fora dos atos de protesto. Eu sugiro que esses protestos/ performances possuem um conteúdo identitário que tem a ver com a reclamação da soberania da Sicília face à militarização histérica duma fronteira imaginária entre o Norte e o Sul do Mediterráneo.

PALAVRAS-CHAVE

MUOS, Sicília, Soberania, Resistência, Performance

1 Doutor em Composição Musical pela University of Leeds (2013). Bolsista PNPD e Professor Colaborador do Programa de Pós-Graduação em Letras: Linguagem e Identidade da Universidade Federal do Acre. 
A Santo Trovato, ${ }^{2}$ in memoriam

\section{Introduction}

The Mobile User Objective System (MUOS) is a military device of global satellite communications owned by the US Department of Defense. One of the MUOS installations was projected and built in Sicily, in a natural preserve, the Sughereta (Suvareta in Sicilian), near the city of Niscemi.

While a fact sheet published by the US Embassy in Italy claims that the "[c]ompletion of [the] MUOS is in the strategic interests of Italy, the United States, and NATO and does not pose health risks to the public" (US MISSION ROME 2015), the widespread antagonism towards the MUOS questions precisely these two arguments.

In particular, judiciary and political institutions in Sicily have drawn upon the health risks posed on the population, ${ }^{3}$ and on

2 This article is dedicated to the memory of Santo Trovato, tireless NO MUOS activist and historical leader of the Sicilian independence cause. Santo released an extremely important declaration for this work on 17 April 2017. He passed away one month later, on 21 May 2017. His strength and passion will always be remembered.

3 This was the position of Sicilian Regional President Rosario Crocetta until 2013 (cf. the fact that the installation is situated on a natural preserve, ${ }^{4}$ in order to momentarily stop the constructions. On top of adducing the same arguments, a composite grassroots protest movement known as NO MUOS also openly disputes the desirability of US and NATO militarisation of Sicilian/ Italian territory.

A widespread argument, which has been formulated long before the construction of the MUOS, claims that the presence of NATO and US military installations in Sicily violates the Paris Peace Treaty (1947), which prescribed the demilitarisation of Italian islands, namely Sicily, Sardinia and the smaller islands (MIGNEMI 1980; DI BELLA 2015; MESSINA, 2015a). The condemnation of the Italian complacency to US and NATO agendas, incorporated in some formulations of this argument (MIGNEMI 1980), has somewhat anticipated the (initial) tensions over the MUOS between the Sicilian Regional Government and the Italian Ministry of Defence, which resulted in the latter suing the former (ROMANO 2013). MESSINA, 2015a).

4 According to the ruling of the Regional Administrative Court (TAR di Palermo) in 2015 (cf. MESSINA, 2015a). 
As I have argued elsewhere, at stake in this particular episode is the question of Sicilian territorial sovereignty, and of whether it is desirable to have it mediated by Italian national interests (MESSINA, 2013, p. 16). As previously reported in my work (MESSINA, 2015a, p. 864), however, the position of the Sicilian Regional Government has changed since 2013, when Governor Rosario Crocetta has become condescending and compliant with the national government. Has I have also reported (MESSINA, 2015a, p. 865), in November 2013 Crocetta has also criminalised the activists, alleging that the Movement was infiltrated by the Mafia.

The grassroots antagonism organised in the NO MUOS Movement brings together all these different arguments and discourses in what Di Bella describes as "popular geopolitics" (2015:334), which refers precisely to a counter-hegemonic vision of the strategic territorialisation operated over Sicily and the Mediterranean by the US and NATO. The Movement combines discourses of health safety and nature preservation with claims about Sicilian sovereignty and broader aspirations for the demilitarisation of the Mediterranean.

In this paper, I examine how the ritual nature of many of the protest forms excogitated by the NO MUOS activists can qualify as performance, and how, conversely, the work of various artists endorses and reproduces protest forms in a way that resembles or represents concrete activism. I then argue that performance-as-resistance and resistance-as-performance not only cooperate in formulating counter-hegemonic discourses against the MUOS project, but also represent fundamental nodes of production of decolonial thought concerned with visions of a demilitarised Sicily and a liberated Mediterranean. Finally, and in contrast with the positions of an anonymous reviewer who has recently assessed an earlier version of this work (ANONYMOUS REVIEWER, 2017), I maintain that the NO MUOS protest is indissolubly linked with identity politics, or, better, with what Walter Mignolo describes as "politics of identity" (2009, p. 14). 
Historical context: Sicily's struggle for demilitarisation and autonomy

On 10 February 1947, in the aftermath of World War II, Italy, Bulgaria, Romania, Hungary and Finland signed a Peace Treaty in Paris with the Allies. Article 43 of the Peace Treaty with Italy prescribed that:

(2) In Sicily and Sardinia all permanent installations and equipment for the maintenance and storage of torpedoes, sea mines and bombs shall be demolished or removed to the mainland of Italy within one year from the coming into force of the present Treaty. (3) No improvements to, reconstruction of, or extensions of existing installations or permanent fortifications in Sicily and Sardinia shall be permitted [...] (4) In Sicily and Sardinia Italy shall be prohibited from constructing any naval, military and air force installations or fortifications except for such accommodation for security forces as may be required for tasks of an internal character (COUNCIL OF FOREIGN MINISTERS, 1946, pp. 18-19).

The pact that established Sicily's demilitarisation was broken shortly after the signature of the Treaty, by the US Navy, that started sending troops to Sicily in January 1948 (MANCUSO, 2009, p. 45). Since then, NATO and US militarisation of Sicilian territory has been very intense, key moments in this process being: (1) The building of the Sigonella Naval Air Facility in 1959 (NAVAL AIR STATION SIGONELLA, 2009, p. 7); (2) The deployment of 112 Cruise missiles in Comiso between 1981 and 1987 (GIANNA, 2007); (3) The building of the Naval Radio Transmitter Facility (NRTF) in Niscemi, started in 1991 (CORADDU, LEVIS \& ZUCCHETTI, 2013); (4) The deployment of Trapani-Birgi airport and of the Sigonella base for the 2011 NATO bombing of Libya, as part of the Operation Unified Protector (NATO, 2011; NATO, 2015); (4) The construction of the MUOS near Niscemi, in the same site that hosts the NRTF (US MISSION ROME, 2015). Local resistance against Sicily's militarisation has been perseverant throughout post-WWII history, ${ }^{5}$ its most tragic episode being the murder of antimissile protest leader Pio La Torre in 1982, which raises suspicions as to the US-based interests that might have been behind it

\footnotetext{
$5 \quad$ My position on local resistance strongly differs from the one held by Lutri (2016), as I will illustrate later.
} 
(AMADORE 2012). The alleged necessity to militarise Sicilian territory acquires additional urgency in light of the current geopolitical division that traces an imaginary North/South border across the Mediterranean (HESS 1978; REIG BRAVO 2015).

The end of WWII was also characterised by the emergence of independence movements in Sicily, which gained electoral consensus in the years immediately following the War, with the MIS (Movement for the Independence of Sicily) gaining 4 seats in the national parliament in the 1946 Italian general elections (CASTAGA 2008:5). In addition, the EVIS (Voluntary Army for the Independence of Sicily) had embarked, since 1944, in armed resistance against the Italian State (PACI \& PIETRANCOSTA, 2010). These years were characterised by frequent massacres committed by the Italian army and the other occupation forces in Sicily (MARINO 2007), including the murder of the commander of the EVIS (Voluntary Army for the Independence of Sicily), Antonio Canepa, in 1945. The momentum gained by Sicilian separatism was among the reasons that induced Italy to concede a Statute of Autonomy to Sicily, in 1946 (PACI \& PIETRANCOSTA 2010: 14). As claimed by various observers, many of the powers conceded on paper by the Statute were either never granted, or granted initially and then slowly eroded (COSTA 2009; MIGNEMI 1980).

Currently, as a result of the failure to achieve factual autonomy and to a great extent also due to the current and continued economic crisis, the traditional political and economic marginalisation of the island in the context of national and continental interests, and its several social problems, such as ever-growing unemployment and mass emigration, have become extremely critical. As evidences of this state of affairs, it is sufficient to mention the recent national investment gap in key areas such as railways and kindergartens (CANNAVALE, 2014). Emigration from Sicily is massive, and around 70.000 people left between 2012 and 2013 (TONDO, 2014). Sicily is also the poorest Italian region in terms of average income (CORRIERE DEL MEZZOGIORNO, 2015) and the unemployment rate 
in the island is $21.0 \%$, against the national Italian average of $12.2 \%$ and the Southern Italian average of $19.7 \%$ (SICILIA INFORMAZIONI, 2014).

In brief, Sicily's situation is markedly characterised by a bizarre contrast between a strategic centrality, enforced by diffused territorial militarisation (and police repression), and an increasing politico-economic peripherality. NO MUOS activists appear to be aware of this situation, and abundantly denounce the unbearable contradictions embedded in this doubly articulated state of subordination to external interests, to the point that the general regional website of the movement has recently commented that

while Niscemi becomes depopulated as a consequence of unemployment, only the number of policemen rises, together with the acts of repression against activists, including imputations and fines! (NO MUOS, 2016). ${ }^{6}$

Since the activists come from varied and often contrasting ideological backgrounds

(DI BELLA, 2015), many of them

6 "Mentre Niscemi si spopola sotto in colpi della disoccupazione, aumenta solo il numero dei poliziotti e degli atti repressivi per gli attivisti, denunce e multe comprese!" may not subscribe to the aforementioned notions of statutory autonomy and/or struggle for independence as desirable ways to achieve the territorial sovereignty they seem to campaign for. However, the necessity of Sicilian territorial sovereignty seems to be an implicit point across the whole movement, which, I contend, ${ }^{7}$ is also abundantly populated by autonomists and independentists (MESSINA, 2015a).

\section{Notes on anthropology, political science and practice-led research}

Anthropological approaches to the study of Southern Italy have produced negative and biased representations of the region's populations and territories. In late $19^{\text {th }}$ century, the Lombrosian School of criminal anthropology theorised the racial inferiority of Southerners and their innate propensity for criminality and illegal behaviours (LOMBROSO, 1900; LOMBROSO, 1896; NICEFORO, 1898). In the middle of the $20^{\text {th }}$ century, the volume The Moral Basis of a Backward Society, written by Edward C. Banfield 7 I will illustrate and address the contentiousness of my point later on in this article. 
after his stay in a Southern Italian village, introduced the widely employed cliché of "amoral familism", to describe the alleged incapacity of Southerners to honour civic interests over family priorities (BANFIELD, 1958). In 1993, drawing abundantly on Banfield's conclusions, David Putnam produced an extremely influential volume of political science, by the title of Making Democracy Work: Civic Traditions in Modern Italy: here Putnam tries to validate the idea that the Italian South, contrary to the Centre/ North of the country, lacks any form of horizontal solidarity, due to a general disaffection towards democratic participation, which originates from forms of vertical exploitation (PUTNAM, 1993, pp. 121-162).

In partially appropriating approaches that pertain to both anthropology and political science I cannot avoid to confront critically the historical legacy of the controversial approaches listed above. Besides actively trying to challenge these representations in my work, I also look at avoiding to achieve any distance from the "object" of my investigation. I can make two concrete claims about this lack of distance: first, I do not qualify as an external observer, but as a (diasporic) Sicilian whose political positions and actions as to the MUOS are coextensive with those of the NO MUOS movement; second, as a composer I am actively including a section on my own musical pieces in this work, alongside the work of other artists.

My first claim perhaps makes my role as a researcher understandable under the concept of "action anthropology" (TAX, 1975), whereby the researcher is actively "willing to make things happen" in terms of helping "a group of people solve a problem" while also "learning something in the process" (TAX, 1975, p. 515). Alongside this fundamental perspective, I also subscribe to Mattos's formulation of a "reverse anthropology" (2015), intended to overturn the traditional scheme that contraposes a "Western" researcher to an indigenous community, alongside the racialised border between humanitas and anthropos (MIGNOLO, 2009). In rupture with this tradition, the work of Mattos, side by side with members of the 
Huni Kuin/Kaxinawa communities of North-West Amazonia, intends to designate those who are traditionally considered a mere object of investigation as teachers/ lecturers of indigenous thought, practices, cultural expressions and technical methods (MATTOS, 2015; MATTOS, HUNI KUIN/ SALES \& MAHKU, 2015).

It is important to clarify that, as seen above, Sicily's provisional and conditional inclusion in what is globally represented as "the West" does hardly alleviate the discursive violence produced as the result of observations conducted by selfproclaimed "Western" observers. Thus, despite the enormous distance between Mediterranean and Amazonian settings, I consider Mattos's approach extremely productive for the examination of Sicily. Moreover, the focus on creative practices and expressions on which reverse anthropology is predicated resonates with the second of my above claims, i.e., that related to my work as a composer/practice-led researcher in composition. In line with this approach, artistic expression is not simply an object whose observation creates knowledge, but a source of knowledge in itself (PACE, 2016; MESSINA, 2013).

Due to the distinctive heterogeneity that characterises my academic activities, the data presented in this work was obtained in a series of different ways, ranging from unstructured interviews with artists/ activists, to personal electronic correspondence and interaction on social media, ${ }^{8}$ through to my own artistic production, created in collaboration with the performers involved according to more musicspecific methodologies. ${ }^{9}$

\section{The No MUOS Movement as} Southern Antagonism

Sicily is situated at the very bottom of a racialised geopolitical divide between the North and the South of Italy (PUGLIESE, 2007). Importantly, this applies to left-wing activism too, in a way that similar grassroots protest

$8 \quad$ I take the opportunity to thank Alessio Micieli, Claudio Scirè, Fabio D’Alessandro, Giuseppe Fiasconaro, Guglielmo Manenti, Maria Rapicavoli, Mario Di Mauro, the dearly departed Santo Trovato, the members of Antenne 46 and Bella Minchiata, and all the other artists and activists who kindly accepted to talk to me in these months/years. The views I express in this paper do not necessarily coincide with their own views.

9 Endless thanks to the Red Note Ensemble, the Portumnus Ensemble, and the Hull Sinfonietta. 
movements elsewhere in Italy are commonly granted much more media coverage than the NO MUOS movement. Italian antagonism is narrated in terms of a prevalently Northern genealogy, which meticulously selects Northern histories of resistance and glorifies them as seminal episodes in the formation of the democratic (white) nation that Italy identifies with. Contrariwise, Southern histories of rebellion are often relegated to the margins of Italian history, when not actively defamed. This trend manifests itself most violently around two historiographical nodes: first, the demonisation and criminalisation of the Southern Post-Unification (1860-1870) freedom fighters known as briganti ("brigands") (GRAMSCI, 1954, p. 68; DICKIE, 1992; PUGLIESE, 2008); second, the official narrative on the Italian Resistance Movement against the Nazi-Fascists at the end of World War II, which represents it as an exclusively Northern phenomenon, overlooking and silencing the role of Southern political movements in the context of the liberation (GRIBAUDI, 1997, p. 86; GRIBAUDI, 2009).
Against this peculiar mortification of Southern histories, Festa (2014) re-signifies the South as an intrinsically antagonist macro-region: the targets of this antagonism are both the criminal organisations and the Italian state, and Southerners are described as making active political use of their own condition of subalternity. This resonates with Pugliese's formulation of "tactical blackening", namely, a "form of grassroots civic culture that reorients the caucacentric, monoglossic nation-state space into a place that is coextensive with southern community histories, politics and cultural practices" (PUGLIESE, 2008, p.13). Importantly, Pugliese and Festa stress on ideas of civic culture in order to disavow Banfield's and Putnam's allegations discussed above.

Coextensively with the resignifications proposed by Pugliese and Festa, in this work the concepts of "resistance" and "movement" are employed precisely to liberate them from the Northern appropriation and monopolisation of Italian antagonism. I subscribe to Diani's 
definition of social movement as a "network of informal interactions between a plurality of individuals, groups and/or organisations, engaged in a political or cultural conflict, on the basis of a shared collective identity" (DIANI, 1992, p. 13). Here it is fundamental to stress on the identitarian element: despite the recent studies by Flesher Fominaya on a tendency towards an "antiidentitarian collective identity" in social movements (2015), the NO MUOS movement can be understood, I contend, as an instance of Southern antagonism, in that, more or less consciously, it underscores continuously its Sicilianness within its activities.

Coextensively with the antagonisms described by Pugliese and Festa, the NO MUOS movement could be described one of the "politico-cultural practices of antidiscipline" (PUGLIESE, 2008, p. 18) that characterises the reclamation of spaces in the South. Pugliese's reference to "antidiscipline" is to be understood as a disavowal of the power of a North-centric Italian state/society over Southern histories and identities. Similarly, in this work, the concept of "resistance" is meant to be very distant from the Italian Resistance Movement narrated as a Northern nationalist founding myth of the Italian Republic: as I have argued elsewhere, the NO MUOS protest pertains to what I describe as "post-Italian", i.e., the Southern Italian articulation of the need to overcome the Italian national horizon

(MESSINA, 2015c; MESSINA, 2016; MESSINA, 2017).

Another important element characterises the NO MUOS protest, namely, a perceived inexorability of the final activation of the MUOS which derives from the enormous power imbalance between the parties involved. In other words, US strategic interests are so powerful in the context of global and local decisionmaking, that many NO MUOS activists may not trust in a final victory of the movement. A comic strip by Guglielmo Manenti, an artist/activist whose work will be examined later in this work, verbalises the perception of this prospected defeat by staging a dialogue between a father and a son, both protesting against the MUOS and dressed as Native North 
Americans: ${ }^{10}$

[Son] "Father, what's the point of keeping on fighting?" [Father] "Fighting is life itself, son" [Son] "But everything has already been decided politically" [Father] "Fighting for things you believe in gives meaning to your life, son". (Figure 1) ${ }^{11}$

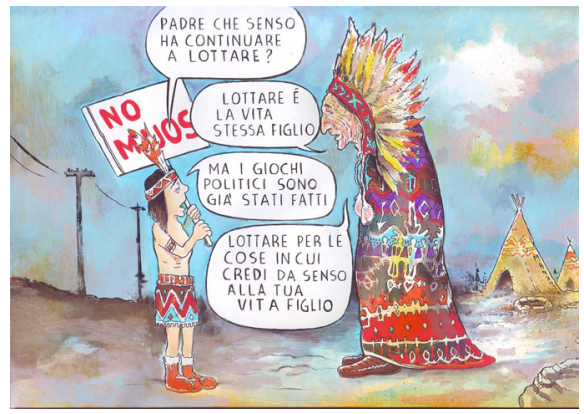

Figure 1 - Guglielmo Manenti 28 March 2015 (reproduced with kind permission of the author)

When confronted with the prospective ineffectiveness of their activities, agents might continue carrying out these activities despite the emerging disconnection between the task and its associated result. This is

10 It is important to note the comic strip resorts to American indigenous identities as a symbol of resistance against colonisation in line with the affinities with Sicily drafted above, while also evoking a problematic model of essentialist exotic wisdom that resonates with the Hollywood cliché of the "Magical Negro", i.e., a subsidiary black character whose wisdom or supernatural powers serve to benefit the white protagonist (GLENN \& CUNNINGHAM, 2009).

11 [Figlio]: "Padre che senso ha continuare a lottare?" [Padre] "Lottare è la vita stessa figlio" [Figlio] "Ma i giochi politici sono già stati fatti" [Padre] "Lottare per le cose in cui credi dà senso alla tua vita figlio". the moment when actions lose their programmatic significance and become performatic. ${ }^{12}$ Tasks turn into rituals, that is, "forms of enacted meaning [that] enable social actors to frame, negotiate and articulate their phenomenological existence as social, cultural, moral, and political beings" (MCLAREN, 1985, p. 85). For example, commenting on the last years of the mattanza (tuna trap fishing) in the Sicilian island of Favignana, Van Ginkel notes that the fishermen continued to practice the trap fishing for more than 10 years, despite its emerged unprofitability. He then argues that the fishermen continued this practice because, "[by] performing the mattanza, the Favignanesi recreate[d] their sense of selves" (VAN GINKEL, 2010, p. 52). To some extent, the various forms of protest excogitated by the NO MUOS activists are comparable to the identitarian obstinacy of the tuna fishermen in Favignana: facing the extreme unlikeliness of a cancellation of the projected intervention, they support their resistance by bringing up their

12 The word "performatic" is distinguished here from the Butlerian concept of "performative": see Hunter (2008). 
own lives, bodies and identities as an ultimate obstacle.

Importantly, in response to the anonymous reviewer (2017), I am not suggesting that the majority of the activists did not hope to eventually win the fight over the MUOS - I am saying that many of them expected that, regardless of the result of every single judiciary/ political battle, US Defense would find a way to implement the MUOS in Sicily, as it eventually did.

As a matter of fact, NO MUOS protests have at times taken the form of artistic performances and identitarian rituals, such as playing cards, singing and making music with various instruments. Before illustrating some of these performatic protests, I will spare another subchapter to dialogue with the existing literature on the NO MUOS Movement.

\section{NO MUOS Literature Review (and a needed clarification)}

I first wrote about the NO MUOS Movement in 2013, in a subchapter of my PhD Thesis (MESSINA, 2013, p. 82-89), and then in three different papers in 2015 (MESSINA, 2015a; MESSINA, 2015b; MESSINA, 2015c). Also in 2015, Arturo Di Bella wrote an extremely important article on the NO MUOS (DI BELLA, 2015), which I have extensively cited in my work. Di Bella is part of a study group on the NO MUOS, mainly based at the University of Catania: other important contributions from this group were published in 2016 by Lutri (2016), and Della Porta and Piazza (2016).

In mid-2016, I submitted an earlier version of this paper for the special issue of an Ethnology Journal. At that time, for purely chronological reasons, I was not aware of the last two papers cited above, both of which I happened to come across soon after my submission. Almost ten months later, after an interminable peerreview process, ${ }^{13}$ I received a series of comments from a reviewer who alleged that I did "not know all the scientific literature on the topic" (ANONYMOUS REVIEWER, 2017), and then cited the very same Lutri (2016), Della Porta and Piazza (2016), together with an earlier chapter by Piazza (2009), as the

\footnotetext{
13 Before the in-house peer-review at the journal, my paper had already gone through a one-year long peer-review process with the two editors of the special issue, whose excellent work I would like to acknowledge. Without them, this article would not have been possible.
} 
important works I had missed.

While I thank the anonymous fellow scholar for her/his precious suggestions and advice, I would like to take the opportunity to engage with some of her/his comments, and with the literature that $\mathrm{s} / \mathrm{he}$ indicated as necessary. Among other things, I do so to respond to the other main complaint issued in the reviewer's report, which revolved around the fact that I had interpreted the NO MUOS as an identitarian struggle, allegedly reproducing "the vision of Sicilian separatists/independentists, which are very marginal in the No Muos Mov[e]ment" (ANONYMOUS REVIEWER, 2017). According to the same fellow scholar, "the way in which the protest is framed, as a conflict between Sicily and Italy/US, is not only simplistic but also not corresponding to the empirical reality" (ANONYMOUS REVIEWER, 2017).

I would like to start this needed self-defence by noting that none of the illustrious colleagues mentioned above does cite any of my published work, despite each of my papers and my thesis being freely and easily available on the internet and listed on multiple academic repositories. In light of this, none of the scholars involved in the present diatribe does actually know the existing scientific literature on the topic in its entirety, unless the anonymous reviewer is trying to suggest that my work is not "scientific". In fact, I have always actively tried to acknowledge other people's work whenever I had the possibility to do so, and the omission of the two 2016 papers was only due to the fact these works were being published exactly when I was about to submit my final draft.

The rest of my self-defence will be focussed on my view of the NO MUOS protest as a struggle for Sicilian sovereignty. Already in its earlier versions, my text contained multiple disclaimers about the fact that autonomy and independence agendas are not uniformly shared by activists, but that I nevertheless see territorial sovereignty as a key component of the NO MUOS protest. ${ }^{14}$ Following my studies in

14 While at the beginning of this article I have mentioned the Sicilian Regional Government and the Sicilian Autonomy Statute, I do not necessarily associate these Italian institutions/laws to Sicilian sovereignty: drawing on Crocetta's aforementioned U-turn on the MUOS, I rather see them as ambivalent entities that may or may not be orientated towards the reclamation of Sicilian 
Amazonian Brazil and Australia, I subscribe to Joseph Pugliese's connection of indigenous sovereignty with a continued practice of social justice in the face of colonial power (PUGLIESE, 2015). In this sense, I cannot refrain from comparing the permanent NO MUOS presidium (DI BELLA, 2015) with the Aboriginal Tent Embassy in front of the Australian Parliament in Canberra, Australia (FELTHAM, 2004); or with the recent Huni Kuin encampments in the Parque Ecológico in Plácido de Castro, Acre, Brazil (ALTHEMAN, 2015), or else, with the Kaiowá/ Guarani's repossession of land illegitimately seized (with state support) by white farmers in the Brazilian state of Mato Grosso do Sul (BRAND, 2016). ${ }^{15}$

\section{Indigenous}

sovereignty

is continuously usurped (PUGLIESE, 2015) by national law, which functions as "an apparatus of biopolitical

sovereignty.

15 At the very moment of finalising this article, a massive demonstration is being led in Brasília by indigenous people of various ethnicities. The protesters demand the demarcation of indigenous lands and have occupied the Esplanada do Planalto, i.e., the land where the national Brazilian Ministries, Government and Parliamentary Chambers are located (GLOBO, 2017). governmentality", on the basis of which the racialised nation-state continuously reproduces itself (PERERA e PUGLIESE, 2012). My comparison between Sicilians and the indigenous populations of Australia and Brazil can only appear unusual if one deliberately ignores the silenced histories of Sicilian and other Southern Italian migrants in various settlercolonial states, or in Northern Italy. In an important article about Australia, for example, Francesco Ricatti identifies a "conflation between Aborigines and Sicilians in Italian migrant discourse" (RICATTI, 2013, p. 126): Ricatti's ground-breaking research shows how, for example, Northern Italian migrants in Australia used to associate the fear and disgust they had of Aboriginals with the fear and disgust they had of Sicilians, precisely on account of specific, conflating constructions of the racialised Other.

The continued military occupation of Sicily, in this sense, cannot possibly be understood without considering the violent racialisation of Sicilians and Southern Italians both within the national Italian territory and in 
the context of the mass emigration of our people in the US. In other words, both Italian and US law apparatuses converge to transform Sicilians, their bodies and their lands, into voiceless objects, "nobodies" (SILVA, 2014a; SILVA 2014b) that can be sacrificed to more important necessities. In his critical analysis of repression in the favelas of Rio de Janeiro, Denise Ferreira da Silva suggests that necessitas ${ }^{16}$ is precisely the discursive ground on which racialised bodies are tortured, killed and sacrificed to guarantee the state's self-reproduction (SILVA, 2014a; SILVA 2014b).

While the activists interviewed by Della Porta and Piazza (2016) may not see this racialisation as a relevant component in the context of the motives of their protest, I argue that a vehement, identitarianly charged reaction against racialisation is omnipresent in the political activities of Sicilians. In order to unveil this omnipresent reaction, I resort to the analysis of cultural production within the protest, confident that it may

$16 \quad$ Necessitas is opposed to selfdetermination, which is granted only to nonracialised communities (SILVA, 2014). reveal sentiments that are not immediately perceivable among the frontline members of the protest.

In the section of this work about the historical context of the NO MUOS, I have noted that the movement is abundantly populated by autonomists and independentists. The anonymous reviewer reacted to this statement, claiming that it lacked "any empirical evidence" (ANONYMOUS REVIEWER, 2017), and then proceeded to point me to Della Porta and Piazza's work, where they report that some groups involved in independentist political activities were expelled from the NO MUOS Movement in 2012, resulting in the formation of a separate Movement, namely the Movimento No Muos Sicilia (DELLA PORTA E PIAZZA, 2016, p. 5-6). Della Porta and Piazza offer an interview with a militant named Alfonso as the only evidence of this claim.

I happen to be in contact with leaders and militants of several independentist organisations, all associated to Movimento No Muos Sicilia, and I asked several of them to confirm whether they 
were expelled from the NO MUOS Movement in 2012. On 17 April 2017, independentist leader Santo Trovato responded to me:

I wasn't aware that anybody had ever expelled us. Regardless of any particular political orientation, we, as independentists, are close to anyone who fights for economic, social and cultural liberation and for the respect of human beings and of their wellbeing. We were, indeed, much closer to the first movements, that emerged spontaneously in Niscemi, Acate and Victoria before the communists of Catania started to appropriate this struggle. (TROVATO, 2017). ${ }^{17}$

Here it is not important to establish who is right about the expulsion of the independence activists: suffice it to say that this is a disputed matter, and that there is no evidence that independentists were marginalised or expelled from the movement. In general, the (unproven) fact that a group of protesters was marginalised/ expelled from a (self-proclaimed?)

$17 \quad$ "Non mi risulta che qualcuno ci abbia mai espulso. Noi indipendentisti siamo vicini, indipendentemente dal colore politico, a chiunque lotti per il riscatto economico/ sociale/culturale ed il rispetto della persona umana e del suo benessere. Siamo stati molto più vicini ai primi movimenti, prima che $\mathrm{i}$ comunisti di Catania si intestassero la lotta, nati spontaneamente a Niscemi, Acate e Vittoria" main movement does hardly make that group marginal in the context of the examination of the protest, unless one wants to (dangerously) legitimise the hegemony of an (allegedly) dominant group within the movement itself. In fact, the members of the Movimento No Muos Sicilia have continued to participate to events, rallies, public assemblies, etc., after 2012 (TROVATO, 2017).

I would like to note that, in Della Porta and Piazza's text, indipendentists are almost always syntactically associated with the extreme right (2016, pp. 5-6), and this suggests a coextensivity between the two political phenomena, which is totally misleading. I agree with Della Porta and Piazza's main argument about the "scale shift" of the NO MUOS protest - from a local territorial dispute into a largescale struggle against war and militarisation - and this has also been one of my arguments since I started working on the topic. I nevertheless refuse to accept Della Porta and Piazza's argument that connects the (alleged) expulsion of independentists from the main NO MUOS movement with 
antimilitarism and antifascism (DELLA PORTA e PIAZZA, 2016, pp. 5-6). Such argument implies that Sicilian independence movements are either populated by militarists, or by fascists, or by both, and overlooks not only the historical importance of antifascism for the history of Sicilian independence activism, ${ }^{18}$ but also the extreme diversity of the current independentist spectrum in Sicily. While I trust these views may reflect the perception of some of the subjects interviewed by the colleagues, I nevertheless recommend that, for this type of work, independence campaigners should be heard alongside other protesters, in order to avoid generalisations and misconceptions.

For the sake of clarity, this work is not about independence movements, nor it tries to reduce the NO MUOS protest to a struggle for Sicilian independence. Moreover, my use of the category of identity ${ }^{19}$ unconditionally refutes essentialist formulations

\footnotetext{
18 The antifascist militancy of EVIS leader Antonio Canepa, for example, is abundantly documented by Paci and Pietrancosta (2010, p. 2).
}

19 As well as, I trust, the use of this category by most independentists. of the concept: I work identity as a socially produced concept (ALBUQUERQUE JR., 2009; ALBUQUERQUE, 2016); importantly, this socially produced concept can also be a necessary component in the collective articulation of a resistance against interventions from above (CUSICANQUI, 2010). In other words, and borrowing again Denise Ferreira da Silva's words, Sicilians are represented and treated as "no-bodies", but the awareness of this discursive imposition makes the "no-bodies" able to unite and fight collectively. It is essential, then, to clarify that Sicilian identity is understood in this work as an attribute that has nothing to do with blood or birth: as a matter of fact, not all of the activists/artists I discuss were born in Sicily, or have Sicilian origins - some of them are not even Sicilian residents. Here I draw upon Walter Mignolo's notion of "politics of identity", which "is different from identity politics - the former is open to whoever wants to join, while the latter tends to be bounded by the definition of a given identity" (MIGNOLO, 2009, p. 14).

What worries me, however, 
is the way in which essentialism operates precisely in the works I am supposed to engage with, according to the anonymous reviewer. On top of having my work labelled as "simplistic" and "not corresponding to the empirical reality" (ANONYMOUS REVIEWER, 2017), I was pointed to a paper by Lutri, on the formation of "new subjectivities" in Sicily within the NO MUOS protest (LUTRI, 2016). The "new subjectivities" unveiled by Lutri seem to refer to the sudden awakening of Sicilians from an habitual condition of passive and condescending subalternity to US neo-colonial agenda: as evidence of this, Lutri only reports his personal views as an antimissile activist during the aforementioned protests in Comiso in the 1980s, when he perceived the local population - except for the militants of the Italian Communist Party - as being hostile towards the protest (LUTRI, 2016). Lutri then proceeds to document the activities of the female protest committee known as "Mamme NO MUOS" ("NO MUOS moms"):

The courageous female participation of women from Niscemiand Caltagirone in this local and regional political controversy emerges as an absolute novelty in their existences, at least as far as the tools and the forms of the protest are concerned. Right from the beginning, the activists of the committee "mamme noMUOS" promoted activities of counter-information by means of public assemblies in Niscemi's main public square, in order to alert the rest of the population as to the risks of the satellite antennas' electromagnetic activity for public health and the environment. They have started direct actions intended to try and pacifically block the installation works of the satellite antennas with their bodies, used for the first time in their lives as political instruments of protest. The women of Niscemi's incorporation of activism and political protest has not only produced in them a new consciousness of what it means to be a woman, a wife and a mother in the political, social and cultural reality of Niscemi (a community that is not much used to participate in political and social life), but has also had consequences in the gender relationships with their partners and/or husbands, who started seeing them not only as mothers and wives, but also as politically active subjects who defend the health of the population and the environment, capable of leading this protest much more than they were before (LUTRI, 2016). ${ }^{20}$

20 "La coraggiosa partecipazione femminile delle donne niscemesi e calatine a questa controversia politica locale e regionale si configura come una assoluta novità nella loro esistenza, per quel che riguarda almeno le forme e gli strumenti di protesta. Le attiviste del comitato "mamme noMUOS" 
Essentially, Lutri seems to subscribe to Banfield's and Putnam's view of Southern Italian communities as naturally opposed to political participation, by implicitly drawing upon a supposed backwardness of Sicilians, a backwardness seen as the fundamental cause of their subalternity. Lutri's "discovery" of women insurgency as a new and unexpected political development in Sicily propitiated by the NO MUOS protest overlooks an entire tradition of female resistance promuoveranno sin da subito in atto delle attività di controinformazione mediante incontri pubblici nella piazza principale di Niscemi, per avvisare il resto della popolazione locale della pericolosità dell'attività elettromagnetica delle antenne satellitari per la salute della popolazione e l'ambiente. Esse daranno vita a delle azioni dirette volte a cercare di bloccare pacificamente con i propri corpi i lavori di installazione delle antenne satellitari, i corpi usati per la prima volta nella loro vita come strumenti politici di protesta. L'incorporazione dell'attivismo e della protesta politica da parte delle donne niscemesi non solo ha fatto emergere tra loro una nuova consapevolezza di cosa vuol dire essere donna, sposa e madre nella attuale realtà politica, sociale e culturale niscemese (una comunità molto poco avvezza alla partecipazione alla vita politica e sociale), ma ha avuto conseguenze anche nelle relazioni di genere con i loro partner e/o mariti, i quali hanno iniziato a vedere queste donne non solo più nel ruolo di madri e di spose, ma anche di soggetti politicamente attivi in difesa della salute della popolazione e dell'ambiente, in grado di trainare anche loro in questa protesta molto più di quanto non lo siano stati sino $\mathrm{a}$ ora" in Sicily and in the South of Italy, which persisted also in diasporic contexts (CALAPSO, 1980; DINO, 2016; COSCO, 2016a; COSCO, 2016b; GRIBAUDI 1997; GRIBAUDI 2010; GRIBAUDI \& MARMO 2010; PALOMBO, 2015); moreover, the allegation that the women of Niscemi and Caltagirone had never conceived their female bodies as instrument of political protest and had never articulated their womanhood, motherhood and wifehood as political concepts before the NO MUOS protest, sounds also extremely paternalistic, especially when coming from a man (as Professor Alessandro Lutri is). Finally, the idea that partners/husbands had never ever seen their companions as political subjects reveals an equally disturbing view of Sicilian masculinity. According to such a text, it would emerge that Sicilians are rebelling precisely because they are liberating themselves from their "Sicilianness", seen as a set of crystallised atavistic attributes such as political passivity, cultural backwardness, endemic patriarchalism, etc.

Lutri's construction of these subjectivities as "new" is trapped 
in a thick web of assumptions that permanently locates Sicily in a periphery, both in spatial and in temporal terms. In this context, the NO MUOS, rather than being seen (as Ithinkitshould) as animportant episode in a whole history of resistance against other-directed apparatuses of geopolitical and biopolitical governmentality, materialises as Sicily's unique occasion of salvation from alleged backwardness. Importantly, this salvation is implicitly oriented in the direction of a normative centre that is allegedly not affected by backwardness and passivity, and that is naturally characterised by civic participation. Needless to say, this centre seems to coincide with Northern Italy, North-America, Northern Europe, etc.

Overall, as I have mentioned earlier, I am worried that the fact that resistance and political participation are generally narrated as Northern prerogatives might induce some observers and academics to (more or less consciously) categorise the NO MUOS protest as a step towards a "necessary" whitening of Sicilians. On the contrary, one of the points I am trying to demonstrate in this work is that the NO MUOS protest is precisely a proud reaction against the normative colonial power of whiteness, both in its national Italian manifestation and in its North-American one.

Finally, and before getting back to my article, I need to gratefully acknowledge the anonymous reviewer's premise, whereby $\mathrm{s} /$ he declares to be a supporter of the NO MUOS like me, and claims not to feel any hostility towards me and my work. As far as I am concerned, this non-hostile attitude is totally reciprocal.

\section{RESISTANCE-AS-PERFORMANCE Turi Cordaro}

The protests staged by activist Turi Cordaro (aka Turi Vaccaro) are often assimilable to artistic performances. On 29 April 2013, he staged a singular protest by resting on the ground in front of a police car, while playing the traditional Sicilian recorder (friscalettu) (Figure 2). The performance, symbolically aimed at impeding the transit of the car, seems based on the consciousness of its nonthreatening character, and yet assumes a powerful oppositional content which seems to disturb the authorities considerably, as 
the officers seem to struggle to figure out what to do in response (MOCCIARO \& FIASCONARO, 2013). Here the activist enacts the obvious contraposition between the human body, that lies in its most inoperative position, and a vehicle characterised by strength and rapidity of action. Additionally, there is a performatic element represented by the recorder played by the activist, which puts individual and community practices, with their ritual dimension, in direct opposition to the immediate exploitation of the site for its strategic utility. This particular significance is not only attributable to Cordaro's protest: on various occasions, for example, while the main group of protesters was blocking access to the site, a smaller group of protesters was sitting on a table, in the middle of the group, playing cards as a form of passive resistance (MOCCIARO \& FIASCONARO, 2013). Again, bodies, rituality, slowness, are set against the immediate access to the site.

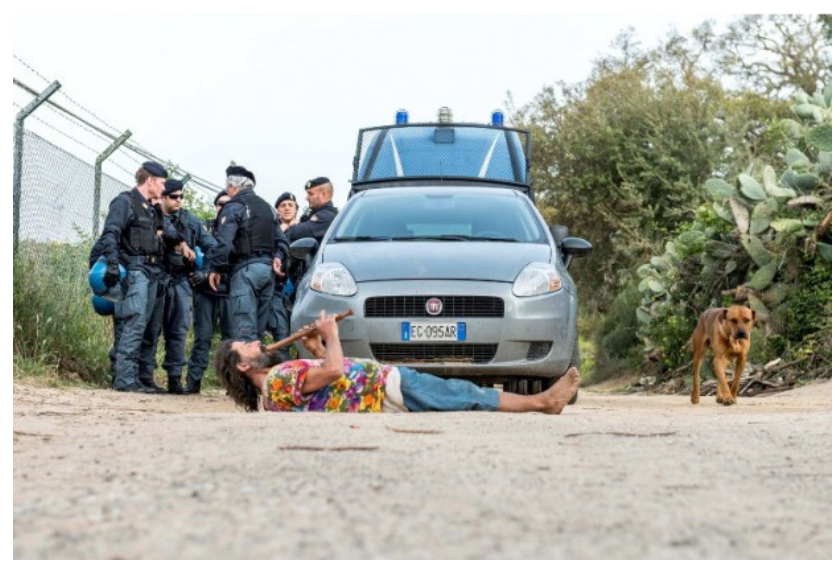

Figure 2 - Turi Cordaro's protest on 29 April 2013 (reproduced with kind permission of photographer Giuseppe Fiasconaro)

Going back to Cordaro's to the construction site. In that individual activities, he seemed to circumstance, while the police be well conscious of the symbolic officers were trying to pull him potential of his performances on the occasion of another incident occurred on 8 May 2013, when he resorted to getting under the wheel of a police van, again in an attempt to prevent access out from underneath the van, Cordaro almost seemed to attempt to use his recorder to hinder the wheel (Figure 3). The resistance of the NO MUOS movement, here epitomised by Cordaro's symbolic 
manifestations, is totally nonthreatening, and yet possesses an intense symbolic power, capable of unnerving the authorities to the point of setting off various acts of reprisals, including random house searches in the activists' habitations (MARKEZ, 2013), and the incarceration of various members of the movement, including Cordaro himself (SICILIA, 2014).

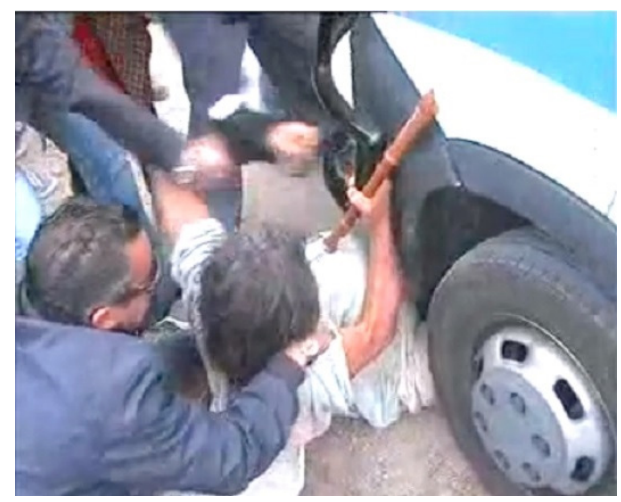

Figure 3 - Turi Cordaro's protest on 8 May 2013 (reproduced with kind permission of photographer Antenne 46).
Another of Cordaro's performances/protests in March and April 2015 involved walking $400 \mathrm{~km}$ from the city of Palermo to the MUOS site to symbolically pour salt on the site (PERROTTA, 2015) (Figure 4). Importantly, the act was meant to celebrate the 1930 Salt March in India started by Mohandas Gandhi. This is probably the most blatant occasion in which the protester almost points to the performatic nature of his NO MUOS activism. The several weeks of Cordaro's March did not in fact involve any sort of material confrontation with the authorities until his very arrival in Niscemi. This slow, prolonged march does not seem to have any particular function if not that of making a point. Cordaro, most probably, links Gandhi's critique of British colonialism in India with his denunciation of the colonial appropriation of Sicilian land.

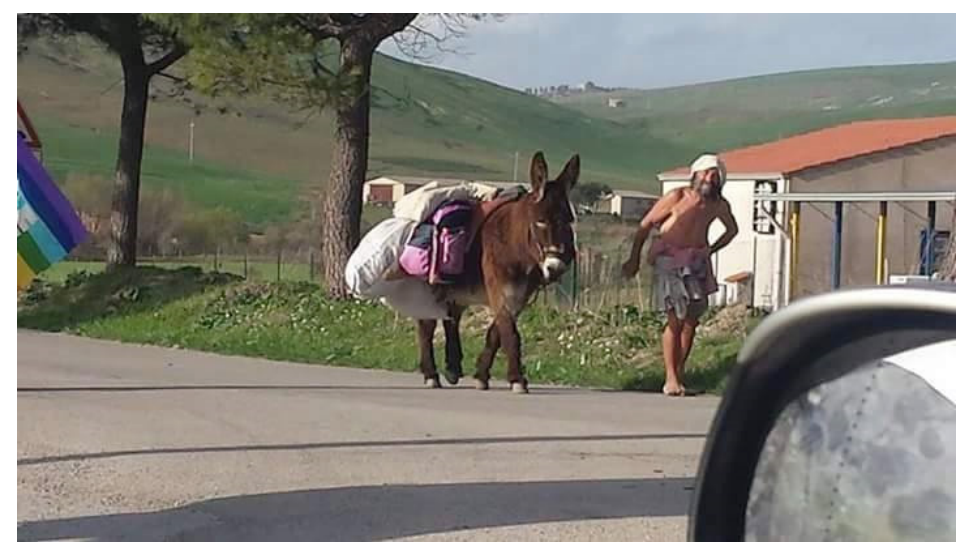

Figure 4 - Turi Cordaro's “salt march” in 2015 (Source: PERROTTA, 2015). 


\section{The "SUCATE” sign}

On 13 February 2015, the Palermo Regional Administrative Court (TAR) had declared the MUOS illegal because it had been built on a natural preserve, the Sughereta (Suvareta in Sicilian) (TAR DI PALERMO, 2015). This was only one chapter of the long and complex judicial battle between Sicilian local institutions and US/ Italy. However, this sentence was particularly significant for the NO MUOS movement, to the point that, to celebrate the decision of the Palermo TAR, a group of activists excogitated a singular manifestation, namely a gigantic sign made of detached white letters leaning against a hill. The sign read "SUCATE" ("Suck it off"), a characteristic Sicilian expression alluding to fellatio that is generally used to deride one's adversary after a victory (Figure 5). The sign was also highly reminiscent of the Hollywood sign, a landmark that commonly symbolises US culture in the global imagery. The "SUCATE" sign also assumes a powerful counter-symbolic charge that is reminiscent of Pugliese's aforementioned notion of grassroots reorienting of a monoglossic space. Specifically, the NO MUOS protesters challenged the authority of the Hollywood sign as a symbol of US success and influence over global culture and as a self-proclaimed bearer of imposed values such as freedom and prosperity; they symbolically disfigured the original Hollywood sign by reproducing it and turning it into an instance of irreverent and blunt defiance; they replaced the glorified English toponym with a rude and desecratory Sicilian expression; by doing so, they celebrated their victory by underscoring its exceptionality in the face of the huge power imbalance between the parties involved. The highly parodic nature of this celebration makes the SUCATE sign also function as a Bakhtinian "decrowning double" of the Hollywood sign, which, as a symbol of the self-celebratory and imperialistic US culture, is laughed at and "force[d] to renew [it]self" (BAKHTIN, 1984, pp. 126-127).

Charged with indecorous phallic references, the SUCATE sign may possess obvious sexist overtones, but points also to the often silenced queer politics of the obscene and of the marginal, of the 
unsuitable and of the indecent, of the desirable and of the repulsive, all of which reverberates sympathetically with what Larissa Pelúcio's describes as Teoria $\mathrm{Cu}$ (PELÚCIO, 2014). ${ }^{21}$ In their performatic act, Sicilian activists are literally inviting the Americans to have sex with them, and by doing this they reposition the terms of the debate from the domains of warfare and court litigation to that of sexual intercourse/domination. Pelúcio attempts to "go beyond translating 'queer', towards thinking of a theory informed by [the] productions [of North American and Northern European queer theorists], but which also dares to invent itself through questioning our own marginalized experience" (2014, p. 1): while Pelúcio seeks to account for Latin America, I see the exercise of Teoria $\mathrm{Cu}$ as applicable to marginalised Southern European communities such as Sicily. In general, queer speech-acts from global peripheries cannot be separated from a passionate decolonial politics of identity, as the SUCATE signs brilliantly exemplifies.

21 The word "cu" literally means "asshole" in Brazilian Portuguese.

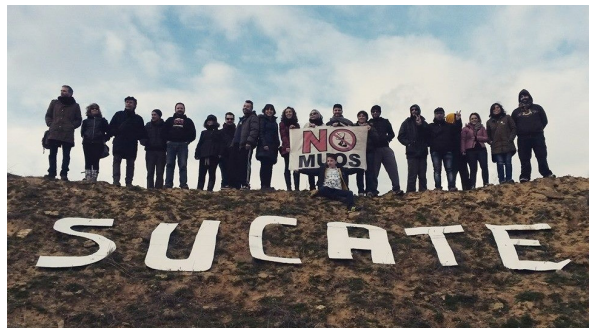

Figure 5: the "SUCATE" sign (reproduced with kind permission of photographer Fabio D`Alessandro).

Bella Minchiata

Bella Minchiata is a group of artists/activists from Catania, dedicated exclusively to the public apposition of the words "Bella Minchiata" (roughly translatable as "What a lovely piece of bullshit") to public buildings, infrastructure and other components of the public space which are deemed to be useless, wasteful, counterproductive, or simply unbearable. Thus, "Bella Minchiata" signs appear from time to time in the urban landscape in the form of graffiti, banners, detached cubital letters, etc. Here the expression "bella minchiata" draws upon the same semantic sphere as the "SUCATE" sign discussed above, as the word minchiata comes from minchia, which denotes the phallus: literally, minchiata is something which is so bad as if it had been done using one's phallus, instead of using one's hands. Here, 
again, the combination of sexist overtones with a radical politics of obscenity, desire and repulsion are as evident as in the SUCATE sign.

\section{Bella Minchiata operates} anonymously: various unidentified groups carry out the intervention, photograph the sign, and then send it anonymously to the Bella Minchiata website and its social network pages. Often, the photo is accompanied by an explanation of the intervention in a comic mixture of Sicilian and Italian. Although Bella Minchiata operates mainly in Catania, in 2016 it "moved" twice to the MUOS site in Niscemi to try and appose its message in the vicinities of the fence of the military site.

The first time they tried was in April. On that occasion, the activist were stopped by the Italian police and military patrolling the site (Figure 6). A short memoire, submitted anonymously with a picture of the act, comments polemically on the role of the Italian police and military in the repression of the NO MUOS protest:

Unbelievable! They stopped us! Even if we, from Bella Minchiata, are very good at not getting caught [...]. I'll tell you what, with these new antiterrorism laws, the cops, or better, the occupation forces, are everywhere: you open the closet, and instead of the monster you find a cop dressed as the monster - the kids can no longer sleep! [...] Those cops saw us with these super-dangerous letters made of polystyrene, [thinking that these letters] could have ruined the day of the Americans [...]. They surrounded us [...], they also took pictures of our documents, as it was obvious that we were people to be afraid of [...]. Dear cops, at this rate, one day you'll find yourselves badly dressed, side by side with us behind the trenches of the slaughterhouses, and you'll cry from your own tear gas, considering how stupid you were when you supported the power with your truncheonshaped dildos, and when you didn't defend the rights of the majority, usurped by a minority. Then we will tell you: you, too, are lovely pieces of bullshit!!! (BELLA MINCHIATA, 2016a). ${ }^{22}$

22 "Mai e poi mai! ci avevano femmato, noi di bella minchiata, siamo bravi a non farin'azziccari [...] Ti dico che oggi con le leggi anti terrorismo, i vaddia, anzi le forze di occupazione sono ovunque, se apri l'armadio, al posto del mostro c'è il poliziotto vestito da mostro. I bambini non possono più dormire [...], comunque chisti ni vistunu cu sta scritta pericolosissima in polistirolo [...] che poteva condizionare la giornata de li Miricani [...]. Ci hanno attorniato [...], Questi ni fecero anche le foto dei documenti, perché si vedeva che eromo gente di cui spaventarisi [...] Cari poliziii, così facendo un bel giorno vestirete loddi, lurdi assieme a noi dietro le trincee dei mattatoi, e vi cadranno lacrimogeni dagli occhi e penserete quanto siete stati stronzi ad avallare il potere 


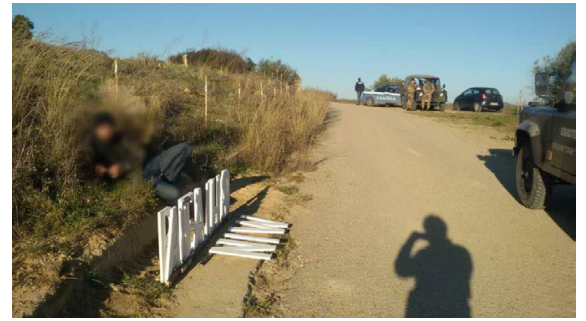

Figure 6: the first, unsuccessful attempt to appose the "Bella Minchiata" sign outside the MUOS site, in April 2016 (reproduced with kind permission of the Bella Minchiata group).

Here, encoded within the goliardic tone of the report, there are discernible assessments of the role of the Italian military as an "occupation force", on the exaggerated repressiveness of the "new antiterrorism laws", and on the exaggerated deployment of forces to counter a few people with "super-dangerous letters of polystyrene". The final lines also articulate a clear dystopic vision whereby the police is expected to share a gloomy future of "slaughterhouses" with common people. The detached polystyrene letters used for this protest are perhaps meant to assume the same decrowning significance as the "SUCATE" sign mentioned above.

A few weeks after the first,

dei potenti con i Dildo a manganello, e a non difendere i diritti rovesciati dai pochi verso i molti. Noi vi diremo a quel punto: siti macari vuatri na Bella Minchiata!!!" unsuccessful attempt, Bella Minchiata returned to the MUOS site and managed to excogitate a way to avoid attracting the attention of the authorities and deliver their "love message" (BELLA MINCHIATA, 2016b) to the MUOS: this was done by setting the camera to long exposure, and "airwriting" the phrase with a lamp (Figure 7). This artifice may only be appreciated in the photo, but it is still an impressive achievement in the face of the disproportionate militarisation of the site.

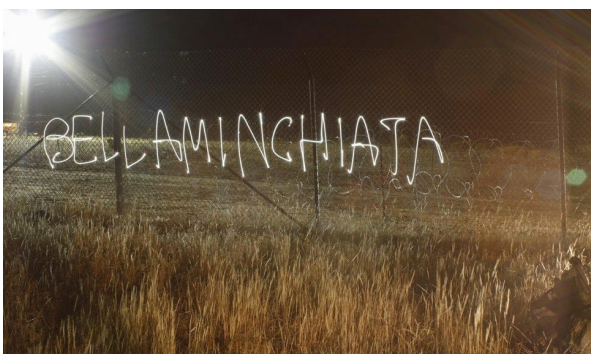

Figure 7: The second, successful attempt to deliver the "Bella Minchiata" message, in May 2016

(reproduced with kind permission of the Bella Minchiata group)

In fact, the exaggerated deployment of repressive forces lamented by Bella Minchiata manifested itself in a megatrial against 129 NO MUOS activists, which was announced in August 2016 by the Gela prosecutor. In commenting this event, Barbagallo talked of a 
conflict of "Italy against Sicily" (BARBAGALLO, 2016), coherently with the aforementioned problem of Sicilian territorial sovereignty and in line with Bella Minchiata's aforementioned description of the Italian military and police as "occupation forces".

Here, again, the anonymous reviewer warns me that this vision of Italy vs. Sicily "is a stretch, a point of view of some people/activists/artists, but not largely shared by the NO MUOS" (ANONYMOUS REVIEWER, 2017). However, I have never claimed to interpret the most widely held opinion of the NO MUOS activists: I am rather trying to interpret acts connected to the protest, in order to unveil the presence of certain identitarian elements that are not dissociable from the whole of the protest itself.

\section{PERFORMANCE-AS-RESISTANCE} Alessio Micieli

Alessio Micieli is an actor/ documentarist from Vittoria, intensely active on YouTube. In his homemade video NO MUOS SICILIA - Il Turista Del Futuro (NO MUOS Sicily - The tourist of the future) (MICIELI, 2014), he appears as a "tourist from the future" with a radiation suit, holding a home satellite dish as the "new souvenir from Sicily" (MICIELI, 2014). In such an outfit, Micieli poses with the MUOS antennas (Figure 8), imitating the silly poses of tourists visiting famous monuments worldwide. He notes that "under the Tower of Pisa there are all those people posing for those weird photos" and then wonders: "here, how are we supposed to pose for photos?" (MICIELI, 2014).

The comparison with the Leaning Tower Pisa, with its global touristic success and its commodified status of universal landmark, perennially consumed and resignified in the most trivial and unnecessary ways by casual travellers, points to the marginalised status of Sicilian land, which is made inconsumable and unsignifiable precisely by the presence of the MUOS installation. Micieli's polemical and caustic comparison between Sicily's ravaged land and Pisa's glorious landmark exposes the blatant contrast between a portion of Italian territory which is abused for strategic, other-directed agendas, and another portion of Italian territory that is among 
the most celebrated touristic destinations in the world.

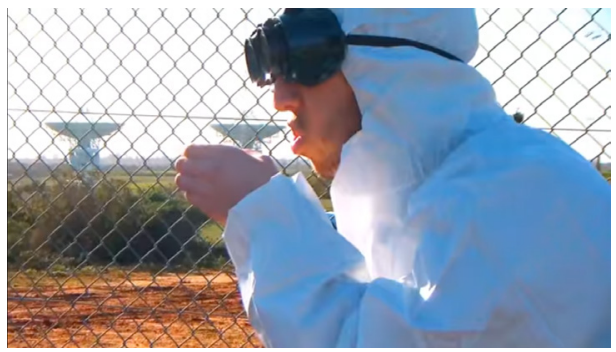

Figure 8: Alessio Micieli doing silly photo poses with the MUOS antennas (reproduced with kind permission of the author)

Dressed in his "touristy" outfit, Micieli then joins a serious NO MUOS protests (Figure 9), standing in the middle of a crowd of protesters as a tourist would stand in a crowded road in Italy's travel destinations.

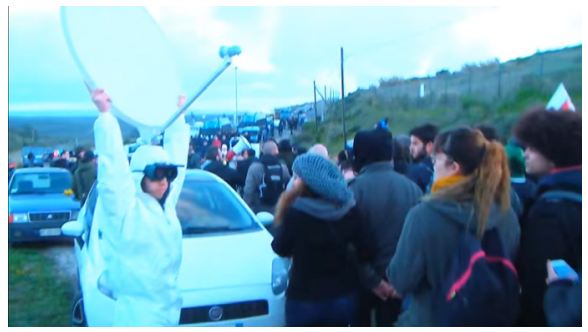

Figure 9: Alessio Micieli dressed in a radiation suit and holding a home parabolic antenna in the middle of a NO MUOS protest (reproduced with kind permission of the author)

Importantly,

Micieli's commentary on tourism is parallel to a commentary on progress and on discursive constructions of the future as a temporal space where to project individual and collective hopes for a better existence. In this sense, Micieli's protest/ performance tackles precisely the colonial discourse of modernity, seen as a series of assumptions about wealth and prosperity that, in reality, underlies a global project of subjugation under a Eurocentric hegemony (DUSSEL, 2000; MIGNOLO, 2009).

As claimed the anonymous reviewer, in previous versions of this work I might have implicitly and unwantedly suggested the fact that the majority of protesters were resigned as to the unlikeliness of a victory against the MUOS (ANONYMOUS REVIEWER, 2017). In fact, it was pointed out that "until the last ruling of the $\mathrm{CGA},{ }^{23}$ most of them hoped in a victory against [the] MUOS" (ANONYMOUS REVIEWER, 2017). In this context, Micieli's absurd performance in the crowd seems to stand out precisely for being rooted in frustrated pessimism, and this is reflected in his status as an outsider, looked at with surprise and confusion by the other protesters (Figure 9). Again, I reiterate the fact that these marginal figures and acts are

23 I will report this ruling in the conclusive section of this article. 
extremely important in order to understand fundamental aspects of the protest that might not be immediately and consciously shared by the large majority of the movement.

\section{Maria Rapicavoli}

Maria Rapicavoli is a visual artist from Catania, also active between Europe and the US. Rapicavoli has explored the issue of Sicilian militarisation in A Cielo Aperto (2014), a solo exhibition hosted by the ISCP in Brooklyn, New York, in February-April 2014. The exhibition brief states that " $A$ Cielo Aperto, an Italian idiomatic expression that can be translated to 'Open Sky' contextualises Rapicavoli's current and longterm artistic research while seeking to open, and therefore disclose, Sicily's sky as a space occupied by military forces" (ISCP, 2014). The exhibition contained a mixture of video, and a "largescale photograph of Sicily's sky" (ISCP, 2014), various pictures of the MUOS, and military maps of Sicily which "the artist acquired from a soldier" (ISCP, 2014).

In fact, Park sees Rapicavoli's reference to the concept of open sky as an ironic remark about the condition of "being in a hermetically sealed space of virtual control" (PARK, 2014:27), where even portrayals of the sky become oddly angled "trapezoids" (PARK, 2014:27), in a way to depict the deforming surveillance of the open aerial space operated by the US military installation. In this context, the map (Figure 8), understood as "an abstraction of physical geography into miniaturized form" (PARK, 2014:27), is exactly the product of this deformation. Thus, Rapicavoli's work seems to point precisely to what Di Bella describes as "a very selective form of geographical knowledge, [whereby] the environmental, social and cultural complexity of territory is overlooked and the site has no intrinsic value except the strategic localisation" (DI BELLA, 2015: 342).

The unrevealed circumstances whereby Rapicavoli received the military map from a US soldier, and the fact that the artist participated in at least one of the Niscemi rallies in 2013 (PARK, 2014, p. 26), suggest Rapicavoli's keen participation in various activities of the NO MUOS Movement, 
and implicitly underscores the and the exhibition in Brooklyn. continuity between her activism

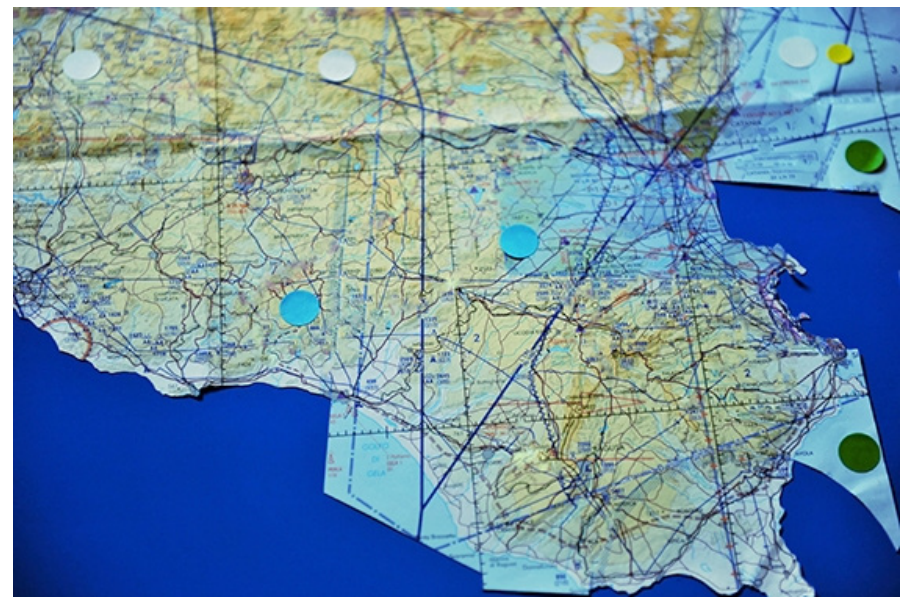

Figure 10 -Map excerpt from Rapicavoli's A cielo aperto (reproduced with kind permission of the author).

The very act of exhibiting in the US work that is critical of US militarisation of Sicilian territory represents undoubtedly an important statement. Rapicavoli implicitly subverts the normativity of US-produced (or US-influenced) discourses about the strategical priorities of Sicilian territory by staging her own counter-discourse precisely within a US-based art venue, which, regardless of any liberal narratives it might foster, can nevertheless be described as a locus of reproduction of national power discourses. This subversion of both the subject of the discourse and the place of the discursive intervention could be seen as what Mignolo defines "epistemic disobedience" (2009), that is, the refusal and the subversion of categories defined by Western consciences and imposed as universal ontological and epistemological parameters in the uninterrupted process of colonial and neocolonial domination.

\section{Blu}

Blu is a male street artist from central Italy, who is only known under his pseudonym. Internationally active, Blu works between the Americas, Europe and the Middle East. In 2013, he painted several walls in Niscemi, most of which engage with the MUOS. 
One of these murals portrays than the monster, and the work a gigantic anthropomorphic obviously displays and reproduces monster, whose head and limbs are the immense power imbalance made of the MUOS antennas. The between the parties involved in giant walks on a surface made of the dispute. At the same time, this war aircrafts and is confronted by a crowd of protesters, one of whom stands out with a megaphone (Figure 9). The protesters appear imbalance is implicitly suggesting a great deal of heroism in the grassroots struggle against the MUOS. to be considerably smaller

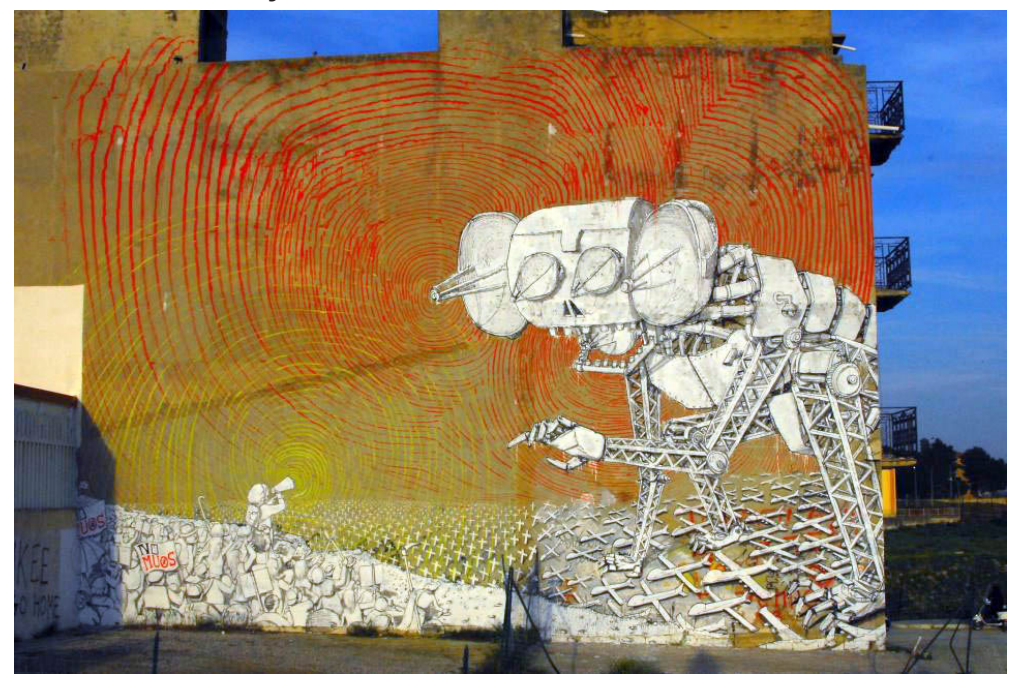

Figure 11 - Blu's street art in Niscemi (reproduced with kind permission of the author).

The depiction of the protest within the work, together with the natural antagonism intrinsic to street art, suffice to describe this painting as activism. Within the suburban landscape of Niscemi, Blu's murals attempt to disrupt the narratives of the strategic US interests right in the site of the intervention, in a way that resembles what Pugliese describes as "Provisional Street Justice" referring to the graffiti on the statue of Dante Alighieri in Naples (PUGLIESE, 2008).

\section{Guglielmo Manenti}

Guglielmo Manenti is a Sicilian NO MUOS activist and cartoonist. He published various comic strips on the MUOS on social media, which were then abundantly displayed at demonstrations by 
the members movement (NANNI e MANENTI, 2014). Similarly to Blu's murals in Niscemi, Manenti's comics abundantly engage with the NO MUOS protest, proudly representing grassroots resistance as a heroic deed in the face of an enormous power imbalance.

The strip displayed in Figure 10 shows an arm wrestling match between an eagle-shaped Uncle Sam and a crowd of protesters shaped as a giant. The general caption reads: "The tug of war continues" ${ }^{24}$, while Uncle Sam nervously wonders: "How many of them are there?".

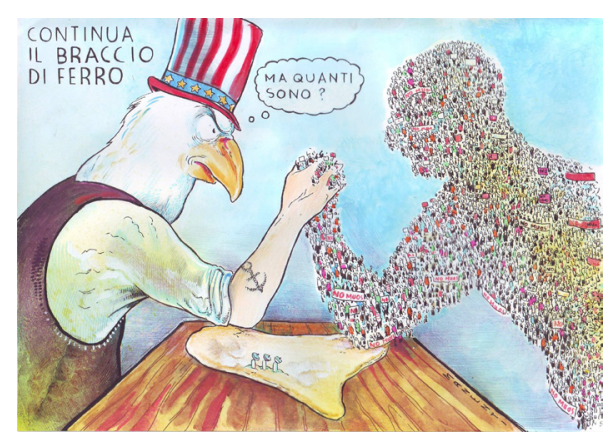

Figure 12 - Guglielmo Manenti, 2013 (reproduced with kind permission of the author)

Here the insurmountable power imbalance between the protesters and the US military agendas is symbolically resolved, and the protesters are able to stand in front of their enemy. In the

$24 \quad$ "Il braccio di ferro continua". "Ma quanti sono?" cartoon, the bone of contention of the arm wrestling match is Sicily, which lies on the table between the eagle Uncle Sam and the protesters: alongside his commentary on the protest, Manenti associates a precise geopolitical argument to his work, an argument about Sicily's condition as a contended territory.

This argument is abundantly articulated throughout Manenti's work, and another comic, shown in Figure 11, portrays Uncle Sam, this time represented as a bloodthirsty human, who banquets on African territory using Sicily as a napkin, and spills blood on both lands. This is another example of what Di Bella defines "popular geopolitics" (2015, p. 334), referring to a variety of emancipatory discourses formulated within the protest, and on which the protest itself is predicated. In a nutshell, Sicily is seen as a colonised territory, whose main function is that of providing land and resources for US foreign military agendas.

\section{Matilde Politi}

This same popular geopolitics is relevant to the work of Matilde Politi, a singer-songwriter from Palermo whose work, among 
other things, is committed with the preservation and diffusion of Sicilian identity, as she often performs in the style of the Sicilian cantastorie (cuntastorii in Sicilian, meaning "storyteller(s)"). In 2013, Politi wrote a song against the MUOS, entitled Cantata NO MUOS, and performed it publicly as part of various NO MUOS demonstrations, including a major rally on 30 March 2013.

In the song, Politi openly condemns US policies since the Allied invasion of Sicily during World War II. The US are accused of having nurtured crime and corruption in order to maintain their control over Sicily and Italy:

The Americans / landed in Sicily and promptly / they made pacts with fascists and criminals / in order to keep the population in poverty / while they could nurture the villains. / There they plotted a detailed project / to keep Italy under their jurisdiction / in order to stop communism at the other side. (POLITI, 2013) ${ }^{25}$

Corruption and crime are also functional to warfare, and Politi

25 ("L'amiricani / Sbarcaru cca 'n Sicilia e prontamenti / s'appattaru cu fascisti e cu Briganti / pri mantiniri u populu a li stenti / nta mentri chi pascevano furfanti / Ddocu 'ntisseru tuttu lu progettu / pi mantiniri a 'Talia 'u so' sirviziu / pi firmari u comunismu dirimpettu"). does not refrain from exposing the US foreign defence policies as a perverse global hegemony agenda:

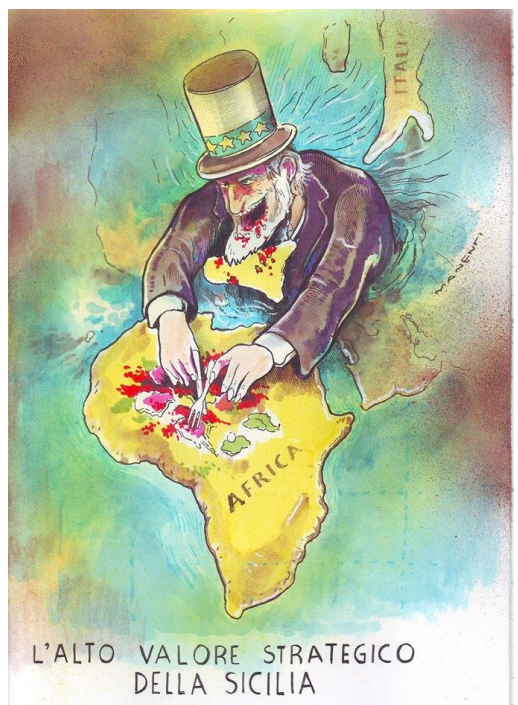

Figure 13 - Guglielmo Manenti, 2013 (reproduced with kind permission of the author)

And henceforth war became an addiction for them. / An addiction that worked almost as a game: / wherever they had won the war / they filled the place with military bases, / Korea, Japan, Germany, Italy or Greece. / In this way, they seized the entire world! / And here, in the middle of the Mediterranean, / every war that they want to do over here, / they can control it from Sicily. (POLITI, 2013) ${ }^{26}$

26 ("E ddocu a guerra addivintau nu viziu / Nu viziu ca pari macari jocu: / a tutti banni unni vinceru a guerra / inchieru 'i basi militari u locu / Corea, Giappone, Germania, Italia o Grecia / Tuttu u munnu accussì strincinu 'mpugnu! / E ccà, nno menzo du Mediterraneo / p'ogni guerra c'a sta banna vonnu fari / di cca 'n Sicilia a ponnu controllari”). 
Politi's focus on the military domination of the Mediterranean operated through the occupation of Sicilian land is coextensive with the narratives offered by Guglielmo Manenti's comics: later in the song, Politi declares that "Sicily wants peace" (2013). The song glorifies the history of the NO MUOS Movement, and the mixture of militancy and spontaneity that characterised its foundation:

At this point people began / to feel uncomfortable, and from that a conversation started / that nothing was able to stop / and the NO MUOS movement was born: / the experience of the old militants / was helpful to the younger ones, / and they decided to form a civic committee / and then to create a regional coordination (POLITI, 2013). ${ }^{27}$

For Politi, the demilitarisation of Sicily has initially to be mediated by the intervention of Italy:

Sicily needs to be demilitarised / Italy needs to get back on its feet / and stand in front of the Americans to end / this eternal slavery sealed by a pact. ${ }^{28}$ (POLITI, 2013) ${ }^{29}$

$27 \quad$ Ddocu la genti tutta ncominzau / a sintirisi nti spini, e dda partiu / un parra parra ca nenti l'astutau / e u movimento NO MUOS nasciu: / ai picciotti l'esperienza s'aggiuvau / di vecchia militanza ca cririu / un comitato cittadino di furmari / coordinamento regionali po' criari.

28 Reference to the 1947 Paris Peace Treaty.

29 Sicilia s'avi a smilitarizzari / l'Italia arreri 'n peri si mittissi / nfacci l'amiricani pi canciari
In the following verse, though, the Italian Government is criticised and insulted, and the task of liberating the island is given back to Sicilians:

This government of fat pigs leads us / to a path that no one likes. / But if people are sovereign / our voice will defeat every abuse, and like embers / on which the Americans are sitting / we are thousands of NO MUOS Sicilians! ${ }^{30}$ (POLITI, 2013)

It thus becomes clear that for Politi, the main issue at stake in the MUOS dispute is the restitution of Sicilian sovereignty, against both US control agendas and Italian complacency. Again, grassroots movements are deemed capable of reverting a situation of undisputable power imbalance, as it is evident in the metaphor of the embers. Politi's song is permeated with a strong trust in the ability of Sicilians to rebel, and she tries to show that this is written in our history:

We fought together against the villains, / so history tells us, and those who deny that / to make us believe we are lambs, / know well that we are lions

\footnotetext{
/ l'eterna schiavitù ca un pattu scrissi

30 Guvernu i porci grossi nni cunnuci / supra 'n caminu c'a nuddu nni piaci / Ma s'u populu è sovranu, a nostra vuci / scunfiggirà l'abusu, e comu braci / sutta lu culu di l'amiricani / semu migliaia di NO MUOS siciliani!
} 
instead! / Our history has been written in the blood / of those who fought with courage and wit, / the cane never bent under the flood, / and (we) always repudiated tyranny. / That's why they've bound us up with chains, / from which Sicilians cannot free themselves: / the Mafia, the Church, corrupted governments, / all of them under the shadow of the Americans (POLITI, 2013). ${ }^{31}$

\section{These passionate claims} seem to challenge precisely the representations of social activism as part of a "new" subjectivity offered, as shown above, by Lutri (2016): Politi tries to reclaim a silenced memory of proud rebellions that appears to have been erased from the contemporary (academic and non-academic) debate on Sicily. This erasure, obviously connected to the aforementioned Northern genealogy of the founding narratives of Italian resistance, is precisely what Pugliese calls "white historicide" (2007). By reclaiming and dignifying the histories of Sicilians, Politi reacts precisely against white historicide.

31 La storia nostra è scritta cu lu sangu / di $\mathrm{cu}$ ha luttatu cu curaggio e 'ncegnu, / sutta la china 'un si calau ddu juncu / e contra la tirannia sempri appi sdegnu / Pi chistu nn'annu misu sti cuddari / ca i siciliani 'un si ponnu allibbirari: / mafia, chiesa, guverni di latruni /sutta lu mantu di l'amiricani
My artistic contributions: Nzikitanza and Not peace, but other things

This last subchapter documents my own artistic responses against the building and activation of the MUOS, in the form of musical pieces. Providing a full description of these pieces is not among the purposes of this work, and here I only mention them and briefly outline the ways in which they might qualify as performance-as-resistance.

Written in 2012 and premiered in the same year by the Red Note Ensemble, Nzikitanza is an instrumental piece for accordion, violin, violoncello and fixed media. ${ }^{32}$ In the piece, I resort to a number of structural constraints and timbral elements in order to celebrate the protest. In particular, I took advantage of the rhythmic staticity prescribed by the ensemble to express a sense of stubbornness and perseverance. I also used repetition in a slightly asymmetrical manner, in a way to break the musical phrase and render an idea of unstable cyclicality. Finally, I used a tape part,

32 In electroacoustic music, fixed media denotes a track that has been pre-recorded or pre-generated and is stored in a support such as a tape, a $\mathrm{CD}$, or a hard disk. 
also requested by the ensemble, to evoke both an atmosphere of serious protest (by using samples from various demonstrations), and of a bold and derisory attitude towards authority (by using various slapstick sound effects). The main purpose of Nzikitanza is that of expressing dissent in a confrontational, yet non-violent manner, in a way to imitate the status of the NO MUOS protest, and in particular of the aforementioned protests by Turi Cordaro (MESSINA, 2015b).

Not peace, but other things is a vocal piece, premiered by the Portumnus Ensemble in June 2013. Here the unescapable constraint imposed on my work was represented by the use of poetry by Philip Larkin. Due to the intensely militaristic content of some of Larkin's works ${ }^{33}$, I decided to arbitrarily juxtapose some of his lines from different poems of High Windows (1984) in order to obtain a pacifistic, antimilitaristic text, which I then set to music:

Man hands on misery to man. ${ }^{34}$ / It deepens like a coastal shelf.

33 I refer in particular to the poem "Homage to a Government", contained in High Windows (LARKIN, 1974).

34 I was not able to modify the explicit androcentric lexicon of this particular verse.
/ The soldiers there only made trouble happen: / Not peace, but other things. / Get out as early as you can, / Next year we shall be easier in our minds. (LARKIN apud MESSINA, 2013).

The text thus obtained seems to address antimilitarism as a general concept without referring to any particular situation, but the composition of this piece was prevalently inspired by the NO MUOS protest. Here I draw upon Mignolo's aforementioned concept of "epistemic disobedience" (2009) in a similar way to what Rapicavoli did with the military maps she obtained from a soldier: both Rapicavoli and I took a text/trace whose very existence serves a militaristic purpose, and subverted it by using it as part of an antimilitaristic work.

\section{Conclusions}

In May 2016, the Sicilian Council of Administrative Justive (Consiglio di Giustizia Amministrativa - CGA) has judged legitimate the authorisations granted to the MUOS (ANSA, 2016). Two months later, the MUOS ground station in Niscemi has been judged legal by the Review Commission (Tribunale del Riesame) of Catania (IACCH, 2016). Often, during the long 
stops imposed by Italian (national and regional) law and politics, the US Department of Defense has continued building the ground station violating sovereign Italian decisions (CASTELVETRANO SELINUNTE, 2013; CASTROGIOVANNI, 2013), and producing further tensions between the activists and the Italian police patrolling the site. In February, 2017, the Italian Supreme Court of Cassation confirmed the legal legitimacy of the MUOS installation (ZINITI, 2017).

In this work, I have attempted to illustrate the mutual permeation between protest and performance as fundamental components of NO MUOS activism. Frequently, a blurred line distinguishes performers from activists, and this two roles are often interchangeable, to the point that an activist like Turi Cordaro could well be described as a performer, while a performer like Matilde Politi, is also commonly involved in activism. Both the "SUCATE" and the "Bella Minchiata" signs also occupy a liminal space between activism and artistic expression, and only a feeble line separates them from Blu's militant street art - perhaps, what distinguishes Blu's art from the other two works is the aesthetic assessment that is normally expected in reaction to his work, an assessment that is not probably expected in reaction to such traces as the "SUCATE" or the "Bella Minchiata" sign. Guglielmo Manenti's comics and Matilde Politi's songs occupy a precise role in the protest, as Politi has sung in various NO MUOS rallies, while banners reproducing magnified versions Manenti's work are often displayed by demonstrators. Alessio Micieli did also produce part of his video during a protest. With respect to Maria Rapicavoli's work and mine, they seem to belong more inflexibly to exhibition venues, concert halls and similar settings: however, both Rapicavoli and I have participated to NO MUOS events and demonstrations outside our role as creative artists and despite normally living outside Sicily.

By examining the various discourses thus produced both within performance-asresistance and within resistanceas-performance, I have also verified that the highly symbolic 
nature of the protests and their ritual/identitarian content do not point exclusively to the specific circumstances of the territory occupied by the MUOS, but broadly address the issue of Sicily's geopolitical role in the face of a growing hysteria that insists on the militarisation of the imaginary North/South border in the Mediterranean. This confirms Di Bella's point about the fact that the NO MUOS protest "cannot be reduced to an egoistic NIMBYism, insofar as the dissent assumes a symbolic and political dimension that goes beyond the defense of an idyllic status quo or of a bounded space" (DI BELLA, 2015: 348); additionally, this confirms Della Porta and Piazza's argument about the "scale shift" of the protest (DELLA PORTA \& PIAZZA, 2016).

\section{The} ritual/performatic dimension of the protest, and its broad geopolitical significance that refuses to address exclusively the specific situation of Sicilian territory, are both intrinsically connected to the aforementioned expectation of a possible defeat. Confronted with the enormous power imbalance between their protest and the US interests behind the implementation of the project, Sicilians resort to the ritual enacting of meaning to express their dissent, and this enacted meaning refers to their specific identity and condition as well as to broader geopolitical issues.

The broad dimension of NO MUOS does not prevent the protest from being indissolubly linked with the issues of sovereignty and identity that I have discussed in this article. On the contrary, I contend, the scale shift envisaged by Della Porta and Piazza is totally coextensive with the focus on Sicilian sovereignty that emerges from my analysis.

To finalise, I will briefly mention the three other MUOS ground stations outside Sicily: two of them are hosted in the US (one in Hawaii and one in Virginia) and one in Western Australia, in Kojarena, $30 \mathrm{~km}$ away from Geraldton. Upon a recent visit to the Aboriginal Tent Embassy in Canberra, it was impossible for me not to notice various placards demanding indigenous sovereignty, surrounded by Aboriginal flags (Figure 14). 


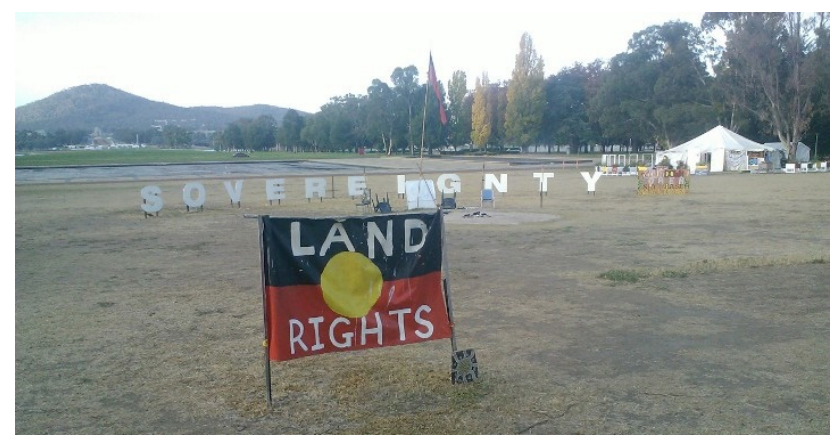

Figure 14: Banners and signs demanding sovereignty outside the Aboriginal Tent Embassy in Canberra, Australia (Marcello Messina's personal archive)

Among these various protest The sign in Figure 15 might well signs, I noticed a banner that represent only a limited and advocated precisely the closure marginal part of the protestagainst of the Kojarena-Geraldton "spy the Kojarenabase, but it is certainly base" that hosts the MUOS Ground understood that US military Station (Figure 15). In Australia, presence in Western Australia is the protest against the MUOS mediated by an illegitimate AngloGround Station is indissolubly White government that has seized linked with the repossession of Aboriginal sovereignty by means usurped Aboriginal sovereignty. of genocide and racial subjugation.

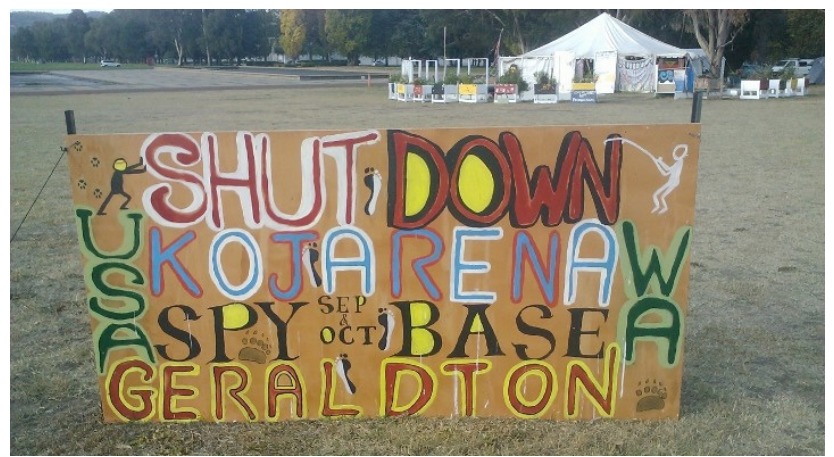

Figure 15: Protest sign against the Kojarena-Geraldton MUOS base outside the Aboriginal Tent Embassy (Marcello Messina's personal archive).

Something similar happens territory is nowadays deployed with Sicily, whose sovereignty was usurped by means of racialised military violence, and whose when Sicilians fight for the 
demilitarisation of their territory they implicitly reaffirm their sovereignty, in the face of the militarised racialisation of their bodies and lands.

\section{Bibliography}

ALBUQUERQUE, G. R. d. Acre. In: Gerson Rodrigues de Albuquerque, Agenor Sarraf Pacheco (orgs.) Uwakürü: dicionário analítico. Rio Branco: Nepan Editora, 2016, pp. 1329.

ALBUQUERQUE JR., D. M. A invenção do Nordeste e outras artes. 4. ed. São Paulo: Cortez Editora, 2009. ALTHEMAN, L. Líder Indígena é ameaçado de morte em Plácido de Castro. O Juruá em tempo. 27 de abril de 2016. https://goo.gl/uHPysP AMADORE, N. Trent'anni fa l'omicidio di Pio La Torre, ucciso dalla mafia legata ai poteri forti. Il Sole 24 Ore, 30 de abril de 2012. https://goo.gl/ TKndf1

ANONYMOUS REVIEWER, Reviewer's report, personal correspondence, 2017.

ANSA, Muos: Cga, autorizzazioni legittime, 6 de maio de 2016, https:// goo.gl/KPbaKz

BAKHTIN, M. 1984. Problems of Dostoevsky's poetics. Minneapolis: University of Minnesota Press.

BANFIELD, E. C. The Moral Basis of a Backward Society. Glencoe, IL: Free Press, 1958.

BARBAGALLO, S.. Italia contro Sicilia: si prepara maxiprocesso contro 129 cittadini "No Muos". La Voce dell'Isola, 31 de Agosto de 2016. https://goo.gl/An1mHD
BELLA MINCHIATA. Bella Minchiata. 24 de maio de 2016a http://goo.gl/ wlFFW9

BELLA MINCHIATA. Bella Minchiata. 21 de maio de 2016b. http://goo.gl/ hqxUQx

BRAND, A. "Quando chegou esses que são nossos contrários"- a ocupação espacial e o processo de confinamento dos Kaiowá/ Guarani no Mato Grosso do Sul. Multitemas, n. 12, 2016, pp. 21-51.

CALAPSO, Donne Ribelli: un secolo di lotte femminili in Sicilia, Palermo: Flaccovio, 1980.

CANNAVALE, A. Sud Italia: un pessimo 2014. Il Fatto Quotidiano, 31 de dezmbro de 2014. https://goo. gl/3GdGZE

CASTELVETRANO

SELINUNTE..

I lavori del MUOS continuano, umiliando i siciliani. Castelvetrano Selinunte, 7 de abril de 2013. https:/ / goo.gl/HiKTYC

CASTROGIOVANNI, L. Caos Muos: Crocetta proclama lo stop, ma i lavori continuano. Buongiorno Sicilia, 18 se Janeiro de 2013. https://goo.gl/ Qi3X8Y

CORADDU, M., LEVIS, A., e Massimo Zucchetti. Biological and sanitary effects of the exposures to non ionizing electromagnetic fields (EMF) and the MUOS case. International Conference of Ecosystems (ICE). Tirana. 2013. 1-7.

CORRIERE DEL MEZZOGIORNO. In Sicilia il reddito annuo più basso d'Italia: $29 \%$ in meno delle altre regioni. Corriere del Mezzogiorno, 19 de fevereiro de 2015. Accessed May 13, 2015. https://goo.gl/gsXJ5] 
Cosco, S. Femminil mostro in brigantesca spoglia: Le donne briganti dell' Italia postunitaria tra realtà e mistificazione. Roma: Aracne, 2016a.

COSCO, S. A literatura sobre o "Brigantaggio" feminino: o caso único de Maria Rosa Cutrufelli. In: RICCI, Debora; RITA, Annabela; VILELA, Ana Luísa; SEVERINO, Isa; SILVA, Fabio Maria da (orgs.) Feminino plural: literatura, língua e linguagem nos contextos italiano e lusófono, Lisboa: CLEPUL, 2016b, pp. 367-376. COSTA, M. 2009. Lo statuto speciale della Regione Siciliana: Un'autonomia tradita? Palermo: Herbita.

COUNCIL OF FOREIGN MINISTERS. Peace Treaty with Italy. Draft Peace Treaties with Italy, Rumania, Bulgaria, Hungary, and Finland. Paris: International Paris Peace Conference, 1946. https://goo.gl/ QHLASa

CUSICANQUI, S. R. Ch'ixinakax utxiwa: una reflexión sobre prácticas y discursos descolonizadores. Buenos Aires: Tinta Limón, 2010

DELLA PORTA, D. e PIAZZA, G., Il cambiamento di scala del Movimento No MUOS: oltre la protesta contro l'inquinamento elettromagnetico, StrumentiRes. Rivista online della Fondazione RES, vol. 8, n. 2, 2016, pp. 1-28.

DI BELLA,A.The Sicilian MUOS Ground Station Conflict: On US Geopolitics in the Mediterranean and Geographies of Resistance. Geopolitics, vol. 20, n. 2, 2015, pp. 333-353.
DIANI, M. The concept of social movement. The Sociological Review, vol. 40, n. 1, 1992, 1-25.

DICKIE, J. A Word at War: The Italian Army and Brigandage 1860-1870. History Workshop, vol. 33, n. 1, 1992, 1-24.

DINO, A. Antimafia e movimenti delle donne. Protagoniste, culture e linguaggi. Rivista di Studi e Ricerche sulla criminalità organizzata, vol. 2 , n. 3, 2016, pp. 3-23.

DUSSEL, E. Europe, Modernity, and Eurocentrism, Nepantla: Views from South, vol. 1, n. 3, 2010, p. 465-478. FELTHAM, Oliver. Singularity happening in politics: the Aboriginal Tent Embassy, Canberra 1972. Communication and Cognition, v. 37, n. 1, 2004, pp. 225-245.

FESTA, F. Oltre l'emergenza: Pratiche ed esperienze di "comune" nel Sud d'Italia. In ORIZZONTI MERIDIANI, Briganti o emigranti: Sud e movimenti tra conricerca e studi subalterni, Verona: Ombre corte, 2014, pp. 191-208.

FLESHER FOMINAYA, C. Autonomous Social Movements and the Paradox of Anti-identitarian Collective Identity In MCGARRY, Aidan e JASPER, James, The identity dilemma. Philadelphia: Temple University Press, 2015, pp. 65-84.

GIANNA, G. I Cruise a Comiso: una scelta non solo strategica. Limes: Rivista italiana di geopolitica, 2 de julho de 2007. https://goo.gl/ RBaqGu

GLENN \& CUNNINGHAM, The Power of Black Magic: The Magical Negro and White Salvation in Film, Journal 
of Black Studies, vol. 40, n. 2, 2009, pp. 135-152.

GLOBO, Índios fecham Esplanada e entram em conflito com PM em ato por demarcação, 25 de abril de 2017. https://goo.gl/Mj3P9i

GRAMSCI, A. L'Ordine Nuovo, 19191920. Turim: Einaudi, 1954.

GRIBAUDI, G. Images of the South: The Mezzogiorno as seen by Insiders and Outsiders. In LUMLEY, R. e MORRIS, J., The New History of the Italian South: The Mezzogiorno Revisited, Exeter: University of Exeter Press, 1997, pp. 83-113.

GRIBAUDI,G.NordeSud:Unageografia simbolica. Contemporanea, vol. 13, n. 1, 2010, pp. 105-118

GRIBAUDI, G. La resistenza vista dal Mezzogiorno. Italia Contemporanea, vol. 255, 2009, pp. 249-256.

GRIBAUDI, G.; MARMO, M. Che differenza fa. Meridiana, n. 67, 2010, pp. 9-20.

HESS, A. C. The forgotten frontier: A History of the Sixteenth-Century. Chicago; Londres: The University of Chicago Press, 1978.

HUNTER, L. A Call for Definitions / Performatics: Making a noun out of an adjective. Performance Research: A Journal of the Performing Arts, vol. 13, n. 2, 2008, p. 7.

IACCH, F. Dissequestrato il Muos di Niscemi. Il Giornale, 6 de agosto de 2016. https://goo.gl/LM3WVJ

ISCP. Maria Rapicavoli: A Cielo Aperto, 2014. https://goo.gl/gU74LS LARKIN, P. High Windows. London: Faber \& Faber, 1974.

LOMBROSO, C. "Il cervello del brigante Tiburzi." Nuova Antologia 150, 1896, pp. 591-600.

LOMBROSO, C. L'ultimo brigante: Giuseppe Musolino. Nuova Antologia, 181, 1900, pp. 508-516.

LUTRI, A.. Contro le antenne MUOS: l'emergere di nuove reti e di nuove soggettività in Sicilia. Dialoghi Mediterranei, n. 18, 2016 https:// goo.gl/G73WMW

MANCUSO, D. Pio La Torre: Una vita per la Sicilia. Thesis: Università di Palermo. 2009.

MARINO, C. G., (org.). La Sicilia delle stragi. Rome: Newton Compton. 2007.

MARKEZ. Coordinamento No Muos: "Perquisite le case degli attivisti". BlogSicilia, março de 14. https:// goo.gl/V1W9c7

MATTOS, A. P. d., A política dos artistas na pedagogia huni kuin? IX Simpósio Linguagens e Identidades da/na Amazônia Sul-Ocidental: línguas e Literaturas Indígenas. Rio Branco. 2015

MATTOS, A. P. d., HUNI KUIN, Ibã, e MAHKU. 2015. Quem é quem no pensamento huni kuin? O Movimento dos Artistas Huni Kuin. Cadernos de Subjetividade, vol. 17, 2015, pp. 1022.

MCLAREN, P. L. The ritual dimensions of resistance: Clowning and symbolic inversion. The Journal of Education, vol. 167, n. 2, 1985, pp. 84-97.

MESSINA, M. Definire il postitaliano Tentativi di superamento dell'orizzonte nazionale italiano nel Mezzogiorno, eleaml.org, 20 de janeiro de 2017. https://goo.gl/ G4TCQ6

MESSINA, M. Narrativas pós- 
italianas A re-imaginação da unidade nacional nas canções do sul da Itália. Muiraquitã - Revista de Letras e Humanidades, vol. 4, n. 1, 2016, pp. 113-125

MESSINA, M. NO MUOS: Practices of Resistance in Sicily against the US Military Communications Satellite System. In ALBUQUERQUE, Gerson Rodrigues de, ISHII, Raquel Alves e NASCIMENTO, Francemilda Lopes do (orgs.), Anais do IX Simpósio Linguagens e Identidades da/na Amazônia Sul-Ocidental: Línguas e Literaturas Indígenas. Rio Branco: Nepan Editora, 2015a, pp. 859-871. https://goo.gl/ojmpdB

MESSINA, M.. Nzikitanza: a piece on the resistance against the MUOS in Niscemi, Sicily. Revista Vórtex, vol. 3, n. 2, 2015b 208-223.

MESSINA, M. "“Nuatri semu un populu pi sempri!”: (De)Coloniality, Autonomism and "Post-Italianism" in Sicilian Songs." Proceeding of the AATI Conference in Siena [Italy], June 17-21, 2015c. Section Cultural Studies. AATI Online Working Papers. https://goo.gl/y3NJoQ

MESSINA, M. Portfolio of Original Compositions with Written Commentary (Examining the Sicilian Question through Creative Composition). University of Leeds: Doctoral Thesis. 2013. https://goo. $\mathrm{gl} / \mathrm{yLKcce}$

MICIELI, A. NO MUOS SICILIA - Il Turista Del Futuro, 3 de março de 2014. https://goo.gl/WW5Kjw

MIGNEMI, G. La questione siciliana: Alla luce delle violazioni al Trattato di Pace con l'Italia, alla Costituzione
Italiana, allo Statuto della Regione Siciliana. 1980, Catânia: Unione Siciliana.

MIGNOLO, W. Epistemic Disobedience, Independent Thought and Decolonial Freedom. Theory, Culture \& Society, vol. 26, n. 7-8. 2009, pp.159-181.

MOCCIARO, I. e FIASCONARO, G. No Muos, nuovi scontri a Niscemi: La polizia solleva di peso i pacifisti. La Repubblica, 29 de abril de 2013. https://goo.gl/56qHVq

NANNI, S. e MANENTI, G., Guglielmo Manenti, arte e impegno civile per resistere al Muos. Osservatorioiraq. it - Medioriente e Nordafrica, 11 de março de 2014. https://goo.gl/48Kfti http://osservatorioiraq.it/puntidi-vista/guglielmo-manenti-arte-eimpegno-civile-resistere-al.

NATO. NATO and Libya. 9 de novembro de 2015. https://goo.gl/ L5CXUW

NATO. NATO and Libya: Sigonella Air Force base hosting Unified Protector. 2011. https://goo.gl/ xiBWR4

NAVAL AIR STATION SIGONELLA. Commemorating 50 Years. Nápoles: Stampa Generale. 1959.

NICEFORO, A. L' Italia barbara contemporanea: Studi e appunti. Milão; Palermo: R. Sandron. 1898.

PACE, I. Composition and performance can be, and often have been, research. Tempo, vol. 70, n. 275, 2016, pp. 6070.

PACI, D. e PIETRANCOSTA, F. Il separatismo siciliano (19431947). Diacronie. Studi di Storia Contemporanea, vol. 3, 2010.

PALOMBO, L. The Racial Camp and 
the Production of the Political Citizen: A genealogy of contestation from Indigenous populations and Diasporic Women. PhD Thesis. Sydney: Macquarie University, 2015. PARK, L. Maria Rapicavoli: A Cielo Aperto. Afterimage, vol. 42, n. 2, 201, pp. 26-27.

PELÙCIO, L. Traduções e torções ou o que se quer dizer quando dizemos queer no Brasil? Revista Periódicus, vol. 1, n.1, 2014, pp. 68-91.

PERERA, S. e PUGLIESE, J., White Law of the Biopolitical, The Journal of the European Association of Studies on Australia, vol. 3, n. 1, 2012, pp. 87100.

PERROTTA, L. La marcia \#Nomuos di Turi Cordaro (fu Vaccaro): A piedi da Palermo a Niscemi, in tempo per il 4 aprile. Meridionews, 30 de março de 2015. https://goo.gl/J6jnd9

PIAZZA, G. Dal locale al globale: le campagne di protesta contro le basi militari in Italia. In LONGO, F., LONGO, MANGANO, A., PIAZZA, G., SAITTA, P., Come i problemi globali diventano locali. Proteste, guerre, migrazioni e deriva securitaria, Messina; Catania, Edizioni terrelibere.org, 2009, pp. 18-45.

POLITI, M. U cuntu "No MUOS". Performed by Matilde Politi. No MUOS Day, Niscemi. 30 de março de 2013. https://goo.gl/dCsrg9

PUGLIESE, J. Geopolitics of Aboriginal Sovereignty: Colonial Law as 'a Species of Excess of Its Own Authority', Aboriginal Passport Ceremonies and Asylum Seekers, Law Text Culture, n. 19, 2015, pp. 84-115.

PUGLIESE, J. Whiteness and the blackening of Italy: La guerra cafona, extracommunitari and provisional street justice. PORTAL Journal of Multidisciplinary International Studies, vol. 5, n. 2, 2008.

PUGLIESE, J. White Historicide and the Returns of the Souths of the South. Australian Humanities Review, n. 42, 2007. https://goo.gl/Raf7nP PUTNAM, R. D. Making Democracy Work: Civic Traditions in Modern Italy. Princeton: Princeton University Press, 1993.

REIG BRAVO, J. Espais de convivència a la Mediterrània. Quadrivium: Revista digital de musicologia, Associació Valenciana de Musicologia, n. 6, 2015. https://goo.gl/qp8DQk RICATTI, F. The Emotion of Truth and the Racial Uncanny: Aborigines and Sicilians in Australia, Cultural Studies Review, vol. 19, n. 2, 2013, pp. 125-149.

ROMANO, A. Muos, la Difesa fa ricorso al Tar: 'Lo stop causa danni diplomatici'. La Repubblica, 25 de abril de 2013. https://goo.gl/qpJu3W SICILIA INFORMAZIONI. Istat, solo un siciliano su tre lavora. Peggio che nel Sud. Sicilia Informazioni, 10 de junho de 2014. https://goo.gl/ TJ4bHZ

SICILIA, D. Turi Vaccaro viola la base MUOS e rifiuta i domiciliari. L'Urlo, 4 de dezembro de 2014. https://goo. gl/UCexxT

SILVA, Denise Ferreira da. Ninguém: direito, racialidade e violência, Meritum, v. 9, n.1, 2014a, pp. 67-117. SILVA, No-bodies: law, raciality and violence, Meritum, v. 9, n.1, 2014b, pp. 119-162. 
TAR DI PALERMO. Sentenza TREATY OF PEACE WITH ITALY. Paris 00461/2015 REG.PROV.COLL. Peace Treaty, 1947. https://goo.gl/ (Tribunale Amministrativo Regionale NAnqtX per la Sicilia - Sezione Prima, 13 de TROVATO, S. Declaration, personal fevereiro de 2015). https://goo.gl/ correspondence, 17 de abril de 2017. FYunSc

TAX, S. Action Anthropology. Current Anthropology, vol. 16, n. 4, 1975, pp. 514-517. US MISSION ROME. MUOS: What It is, What It's Not. 2015. https://goo. gl/APbnwF

TONDO, L. L'emigrazione svuota ZINITI, A. Il Muos di Niscemi non l'Isola ogni anno partono in 35 mila. La Repubblica, 12 de janeiro de 2014. https://goo.gl/jJrLRL è abusivo, l'impianto restituito al ministero della Difesa, Repubblica (Palermo), 10 de fevereiro de 2017. https://goo.gl/YFNtbP 